\title{
Microbial trait-based approaches for agroecosystems
}

Sascha M.B. Krause ${ }^{1 *}$, Stefan Bertilsson ${ }^{2}$, Hans-Peter Grossart ${ }^{3,4}$, Paul L.E. Bodelier ${ }^{5}$, Peter M. van Bodegom $^{6}$, JayT. Lennon ${ }^{7}$, Laurent Philippot ${ }^{8}$ and Xavier Le Roux ${ }^{9}$

${ }^{1}$ School of Ecology and Environmental Sciences, East China Normal University, Shanghai, China

${ }^{2}$ Department of Aquatic Sciences and Assessment, Swedish University of Agricultural Sciences (SLU)

Uppsala, Sweden

${ }^{3}$ Leibniz-Institute for Freshwater Ecology and Inland Fisheries, Berlin, Germany

${ }^{4}$ Institute for Biochemistry and Biology, Potsdam University, Potsdam, Germany

${ }^{5}$ Department of Microbial Ecology, Netherlands Institute of Ecology (NIOO-KNAW), Wageningen, Netherlands

${ }^{6}$ Institute of Environmental Sciences, Leiden University, Leiden, the Netherlands

${ }^{7}$ Department of Biology, Indiana University, Bloomington, IN, USA

${ }^{8}$ University Bourgogne Franche Comte, INRAE, AgroSup Dijon, Department of Agroecology, Dijon, France

${ }^{9}$ Ecologie Microbienne, INRAE, CNRS, Université de Lyon, Université Lyon 1, VetAgroSup, UMR1418,

UMR5557, Villeurbanne, France

*Corresponding author

Sascha M.B. Krause

School of Ecology and Environmental Sciences,

East China Normal University, Shanghai, China

Email: smb.krause@gmx.com 


\section{Abstract}

Conventional agricultural practices negatively impact soil biodiversity, carbon stocks, and greenhouse gas emissions in ways that make them unsustainable for supporting future supply of food and fiber. Better management of agrobiodiversity will likely play a critical role in transitioning towards more sustainable practices. In particular, innovation and developments targeting the aboveground and belowground components of agroecosystems should be informed by frameworks and approaches that harness the -in particular functional- diversity of complex microbial communities. Here, we review and discuss microbial trait-based approaches that will help us understand and steer agroecosystem functioning in the face of global change. We highlight how trait-based approaches can improve agricultural practices related to soil functioning (e.g. soil fertility and aggregation); climate regulation (e.g. carbon storage and greenhouse gas emissions) and adaptation to climate change; plant health; and reduction of contaminant-related hazards for human health. We also consider how microbial trait-based approaches can be used as a tool to improve cultivated plant performance through artificial selection and microbiome engineering. Last, we discuss the inherent obstacles associated with the development and implementation of trait-based approaches owing to strong interactions within microbial communities and linkages between plants and the soil environment. Despite these obstacles, microbial trait-based approaches hold promise for the sustainable management of agricultural ecosystems needed to feed and nourish a rapidly growing human population.

Keywords: Agriculture, ecological theory, innovative agricultural practices, microbial functional diversity, microbiome-associated plant phenotypes, plant-soil feedbacks, soil functions 


\section{Introduction}

Agroecosystems comprise almost $40 \%$ of earth's land surface area and provide food, biofuels, and fibers to a growing world population (FAOSTAT, 2021). However, the typical high level of productivity in such systems rely on intense agricultural management and practices that influence and often compromise important ecosystem functions and services, including groundwater renewal and purification, soil fertility, climate regulation, and the suppression of pathogens and pests (Dornbush and von Haden, 2017; Foley et al., 2005; Power, 2010). It is obvious that past and current agricultural intensification will not be sustainable in the long run and this calls for alternative practices that consider both agricultural production needs and sustainable provision of critical agroecosystem services (Pe'er et al., 2019).

There is consensus that biodiversity is a key element in sustaining the functioning of agricultural systems (Brunetti et al., 2019; Dainese et al., 2019; Ortiz et al., 2021). In particular, belowground soil biota is increasingly recognized as an important component for the functioning of agroecosystems. Among these biotas, microorganisms represent an indispensable component of both natural and managed ecosystems (Bardgett and van der Putten, 2014; Fierer, 2017). In agroecosystems, soil- and plant-associated microbial communities can improve soil health by storing carbon (C), regulating nutrient cycles, and contributing to maintain or restore soil physical structure (Garnica et al., 2020; Kibblewhite et al., 2008). In these ways, soil microbial communities have direct and indirect effects on plant health, including plant growth and plant-associated suppression of pathogens, as well as plant nutrient use efficiency (Backer et al., 2018; Carrión et al., 2019; Harbort et al., 2020). However, modern agriculture practices prioritize high yield with a low number of plant species or 
varieties, which can have unintended or negative impacts on soil- and plant-associated microbial communities with undesirable long-term consequences for soil quality and crop yield (Banerjee et al., 2019; Mariotte et al., 2018; Matson et al., 1997). Accordingly, the integration of belowground microbial diversity into agricultural management strategies is increasingly recognized, and in many cases is considered necessary, for meeting the challenges of sustainable and multifunctional agroecosystems (Bender et al., 2016; Ray et al., 2020; Verbruggen et al., 2010).

To better appreciate the role of microbes in agroecosystems, there is growing emphasis on functional traits or functional diversity of crops as well the associated above and belowground microbiome (Barot et al., 2017; Bender et al., 2016; Wood et al., 2015). Functional traits are defined as behavioral, morphological, and physiological characteristics that influence the performance or fitness of an organism under a given set of environmental conditions (see glossary in Table 1) (Lavorel and Garnier, 2002; Lennon et al., 2012). Traits not only determine how organisms respond to their environment but are also related to how organisms affect their environment. In this way, traits are useful for making mechanistic links between biodiversity and ecosystem functioning (Cadotte et al., 2011; Escalas et al., 2019). A systematic search of published papers reveals that trait-based approaches have been increasingly applied in ecology of both plants and microorganisms in recent years (Figure 1). However, a closer examination reveals that such trait-based approaches are rarely investigated in agroecosystems (Figure 1). This may be due in part to knowledge gaps concerning the critical components of microbiomes in agricultural systems. If so, this is somewhat surprising because microbial trait-based approaches provide opportunities to circumvent many of the issues and challenges that arise 
with the historically widely used taxonomic classification approaches that often cannot capture the vast differences in ecological and physiological functions associated with taxa in their realized phenotypes (Green et al., 2008; Krause et al., 2014a; Staley, 2006). Using traits not in a solely explanatory manner, but by also leveraging the predictive and integrative power of these approaches, there is potential to assess the validity of ecological theories and models to mechanistically understand and manage ecosystems (Lajoie and Kembel, 2019). In an agriculture context, focusing on the link between management, microbial traits, agroecosystem functions, and services might indeed enable better predictions of the interplay between important soil processes, the contributing microorganisms, and the environmental conditions that control them (Figure 2) (Kallenbach et al., 2019; Le Roux et al., 2016). This is even more important as crops and plants, in general, are nowadays not considered as purely vegetal entities but as interacting and in some cases co-evolved systems formed by the long-term associations of host plants and their microbiome (Vandenkoornhuyse et al., 2015).

In this chapter, we synthesize the potential of applying functional trait-based approaches for the development of sustainable agricultural practices (Figure 2). First, we briefly discuss why trait-based microbial ecology is particularly relevant to agroecosystems and their management. We then present an overview of compiled examples of microbial trait-based approaches that we think are important for developing productive and sustainable agricultural systems. Finally, we provide suggestions on how to improve the selection and use of crop varieties and how to steer the soil microbiome using a microbial trait-based perspective.

\section{From taxonomy to traits: getting a grip on microbial diversity in agroecosystems}


The influence of organisms and their diversity on ecosystems is through the functions they perform. This also applies to microorganisms. In agricultural systems, soil microorganisms are involved in many important processes such as the decomposition of organic matter and recycling of nutrients for plant use, transformation, and degradation of pesticides, and as the culprits causing greenhouse gas (GHG) emissions, but also in mitigating such GHG release. These impacts of (micro)organisms can be expressed and predicted in terms of organismal functional traits (Table 1). Given that traits do not only relate to the impacts of organisms on ecosystem functioning (i.e. effect traits), but conversely, also to the response of organisms to environmental impacts and pressures (i.e. response traits), trait-based approaches have also generated important insights into eco-evolutionary strategies of organisms (Li et al., 2021).

While there are many examples in the literature of how trait-based approaches have been applied to plants (Van Bodegom et al., 2012), studies have increasingly become available on virtually every organismal group. Examples include aquatic invertebrates (De Bie et al., 2012), birds (Sheard et al., 2020), mammals (Cooke et al., 2019), and microorganisms (Martiny et al., 2012). In many studies, trait-based approaches appeared to have more power than taxonomicbased approaches (including measures of species richness) for predicting community- and ecosystem functioning for microbes as well as other organisms (Escalas et al., 2019; Salles et al., 2009; Zakharova et al., 2019). Consequently, the use of microbial trait-based approaches is promoted by the scientific community, also for agricultural ecosystems (Wood et al., 2015).

More specifically, microbial trait-based approaches are promoted by a shift from single gene taxonomic approaches (e.g. targeting 16S, 18S, ITS, or any other taxonomic marker) to metagenomic, transcriptomic, and proteomic approaches and studies of interaction networks in 
which traits or clusters of traits can be robustly identified, thus going beyond knowing the mere presence of microbial lineages (Krause et al., 2014a). An example of microbial trait-based approaches that merged traits into axes of eco-evolutionary strategies is that relating $\mathrm{r}$ vs $\mathrm{K}$ strategies (Allison and Gessner, 2012). The $r$ - and K-selection framework on ecological strategies (Dobzhansky, 1950), which has also been applied to microbes (Fierer et al., 2007) states that environmental characteristics will be reflected in the fitness or life-history traits of prevailing organisms. This distinction has been useful to show, e.g., how microbial impacts modulate the effects of nitrogen amendments and $\mathrm{CO}_{2}$ fertilization on soil $\mathrm{C}$ accumulation (Wieder et al. 2015). However, this framework has been developed for animal life strategies whereas also microorganisms display many characteristics that are typical for plants, e.g. clonal growth, dormancy, limited mobility, and 'seed' banks. Therefore, efforts have been made to develop a framework for microorganisms analogous to that already existing for plants, i.e. the Competitor-Stress tolerator-Ruderal selection framework (C-S-R) (Grime, 1974). 'Stresstolerators' can cope with low resource levels or otherwise unfavorable abiotic conditions, 'Competitors' can outcompete other organisms for space or resources, and 'Ruderals' are fastgrowing and post-disturbance re-colonizing organisms. The C-S-R framework can be used to calculate the response to stress, disturbance, and competition, and offers more flexibility to account for the vast metabolic flexibility of bacteria (Ho et al., 2013; Krause et al., 2014a; Malik et al., 2020). Malik and colleagues (2020) proposed a different perspective on the C-S-R strategies by replacing the ruderals strategy with high growth yield $(\mathrm{Y})$ strategy and the competitor strategy with resource acquisition strategy (A). The authors suggest that the Y-A-S strategies reflect many of the key traits that drive microbial community function and that 
tradeoffs in resource allocation prevent assigning multiple strategies to microbes. Overall, use of life history strategies is an appealing way to reduce thousands of potential traits to a smaller number of quantifiable traits and strategies, thus helping to classify how microorganisms respond to different environmental conditions as a result of physiological and evolutionary tradeoffs.

Also, classical microbiology studies that have focused on morphological or biochemical traits may be considered trait-based approaches avant la lettre. With respect to physiological traits, microbial growth yield or C use efficiency (Manzoni et al., 2012), growth rates and maintenance requirements and dynamics have so far received a lot of attention in systems ranging from sludge reactors to soil and deep subsurface systems. For instance, van Bodegom (2007) showed how there is a tradeoff between fast growth and perseverance under nutrient scarce conditions because of high maintenance costs. Kempes and colleagues (2017) investigated processes controlling maintenance costs and their coupling to microbial cell size. Also, other fundamental physiological trade-offs, e.g. between maximum uptake capacity and substrate affinity, have been identified (Litchman et al., 2007). In addition, phylogenetic constraints of being a resource generalist or specialist have been highlighted as major determinants of eco-evolutionary strategies (Nelson et al., 2016). These relationships are central for understanding and predicting microbial ecological functioning in agroecosystems.

\section{Challenges of applying a genetically grounded functional trait concept from macro- to}

\section{microorganisms}

The concept of functional traits (Table 1) in ecology is based on eco-evolutionary selection. Traits are used to explain differences in fitness that are inherited from one generation to the 
next (Lajoie and Kembel, 2019). This works well for animals and plants which transfer traits vertically to their offspring. However, microbes also have the potential for extensive horizontal gene transfer (Gogarten et al., 2002; Polz et al., 2013), and their functional traits might accordingly be decoupled from the evolutionary history of the vertically transmitted parts of the microbial genome and their phylogenetic identity (Martiny et al., 2015). For instance, this explains why the coupling between phylogenetic relatedness and functional similarity can be weak in microbial groups such as denitrifiers (Salles et al., 2012). This raises the central question of whether or not microbial traits that are important for determining the distribution and impact of biodiversity in agroecosystems are taxonomically conserved. If this is the case, it would be possible to predict microbial agroecosystem services by using phylogenetic diversity as a readily accessible proxy for trait diversity. We argue that trait-based approaches tailored to agroecosystems should not simply replace taxonomy-based approaches but build on this foundation. Previous research has indicated that microbial traits can at least to some degree be taxonomically conserved through evolutionary timescales (Krause et al., 2014b; Lennon et al., 2012; Philippot et al., 2009). However, a comprehensive analysis highlighted that different traits seem to be conserved to variable extents (Martiny et al., 2015). In particular, traits such as the ability to grow at different $\mathrm{pH}$ and salinity seemed to be deeply conserved while traits linked to the utilization of $\mathrm{C}$ or organic phosphorus showed only marginal conservatism. This is exemplified by the weak phylogenetic signals observed for grassland soil bacteria or archaea regarding their response to $\mathrm{N}$ or $\mathrm{P}$ additions (Ma et al., 2019).

Also, the ability to fix atmospheric nitrogen is only marginally conserved and is shared by many free-living and symbiotic bacteria and archaea. This process, biochemically mediated by 
nitrogenases, is energetically costly but can be stimulated by plants fueling the process with organic exudates that may also enhance plant productivity. Interestingly, nitrogen fixation capability can be transferred horizontally (Yan et al., 2008) and the occurrence of the trait is patchy across the bacterial and archaeal domains. Diazotrophs in soils are highly diverse with Proteobacteria, Chlorobi, Firmicutes, and Cyanobacteria being dominant member groups (Nelson et al., 2016). Except for Cyanobacteria, diazotrophs with the capacity to fix nitrogen can couple this with other nitrogen transformation traits (e.g. ammonia assimilation ability, dissimilatory nitrate reduction to ammonia, nitrification, denitrification). This underscores the evolutionary and functional significance of genomic context and linkages of traits at the cellular level. It further points to the challenges in describing and factoring in traits in complex microbial communities based on strictly taxonomic information.

Fitness differences induced by traits can lead to eco-evolutionary feedbacks (EEFs, Table 1) (Fussmann et al., 2007; Schoener, 2011). In agroecosystems, EEFs are manifested through the typically tight functional linkages between plants and microorganisms. This results in microbial traits affected by constantly evolving genetic variation in plant traits while conversely the microbial communities and their traits can change the evolutionary path of plant traits (Bardgett and van der Putten, 2014; terHorst and Zee, 2016). For instance, it has been demonstrated that under drought stress, microbial communities and more specifically their drought-adapted functional traits, not only increase plant fitness but also impact selection acting on a broader range of plant traits (Lau and Lennon, 2012). Another study used the rhizosphere dweller Pseudomonas protegens on roots of Arabidopsis thaliana as a model and demonstrated that evolutionary dynamics can restructure phenotypic trait organization and 
result in new networks of covarying traits which were not expressed in the original phenotype (Li et al., 2021). Given the general importance of EEF, it is certainly useful for us to understand the processes underlying the dynamics of EEFs of plant and microbial trait evolution in a rapidly changing environment.

EEFs of functional traits may also be related to epigenetic processes in plants and microorganisms (Casadesús and Low, 2006; Herrel et al., 2020). Epigenetics describes a generally reversible process of transcriptional regulation, such as methylation, that is not encoded in the DNA sequence (Willbanks et al., 2016). As such, epigenetic variation provides a direct link of genomic information to the environment (Rey et al., 2020). Two important aspects are of relevance for trait-based approaches in agroecosystems. First, indirect approaches using genomics or transcriptomics to quantify functional traits may be hindered by phenotypic plasticity introduced by epigenetic modification. Second, epigenetic mechanisms can play a role in the interaction between plants and microbes (Alonso et al., 2019; Zhu et al., 2016). For instance, it has been suggested that pathogenic bacteria can induce epigenetic regulations in the host cell, either promoting host defense or allowing pathogen persistence (Alonso et al., 2019; Bierne et al., 2012). As a result, functional traits related to pathogenicity may display different responses in fitness that cannot accurately be predicted before this process is fully understood. The integration of epigenetics in ecology and evolution is still an emerging field (Herrel et al., 2020; Verhoeven et al., 2016) and the capacity of this type of regulation to increase trait flexibility and alter microbial/plant interactions needs to be better evaluated.

\section{Dormancy, a further challenge when applying microbial trait-based approaches}


Dormancy is an important trait of microorganisms living in agricultural soils. Numerous studies have reported that a large fraction, in some cases $90 \%$ or more, of the soil microbial community is metabolically inactive at any given point in time (Alvarez et al., 1998;

Blagodatskaya and Kuzyakov, 2013; Lennon and Jones, 2011). Dormancy conserves the legacy of past environmental impacts and diversity and thus can mobilize capacities inherited from past conditions while contributing to current microbial responses to environmental changes (Krause et al., 2018). As such, the accumulation of dormant individuals leads to the creation of a "trait seed bank", which is an important reservoir of genetic, phenotypic, and functional traits that can influence ecological and evolutionary dynamics. For instance, recent findings suggest that dormancy can increase the ability of microbial ecosystem functions to buffer environmental disturbances (Kearns and Shade, 2018). But, it remains a challenge to determine how traits from dormant individuals are initiated in their realized phenotype and reflect the response of microbes under changing or novel environmental conditions. In addition, dormancy modifies species interactions in ways that contribute to the maintenance of biodiversity, for example, through the "storage effect" (Warner and Chesson, 1985). In the context of "micromanaging" microorganisms for ecosystem services (Peralta et al., 2014), dormancy is likely important for sustaining beneficial interactions with plants and other taxa found in soil food webs, but could also help explain the persistence of pathogens and microbial antagonists. For example, the disruption of microbial seed banks has recently been shown to alter the structure and function of belowground communities in ways that have implications for the growth and performance of plant populations (Kuo et al., 2021). 


\section{The need to assess traits through the lens of community interactions to produce actionable knowledge for agricultural systems}

Microbial traits relevant for plant health and agricultural production are typically elusive and hard to identify and to account for at the level of individual bacterial, fungal or archaeal strains or populations. One underlying reason is the complexity of soil and rhizosphere microbial communities with a typically high degree of interactivity that often overrides autecological properties and traits (Johansson et al., 2004). Additionally, certain traits are only manifested in the presence of others. Dynamic competition, antagonism, and mutualism may modulate traits of individuals. Likewise, trait distributions can be highly context-dependent and in essence require a broader characterization of communities to be of practical value. This becomes evident in the many failed attempts to robustly and consistently promote cultivated plant health and production by amending agricultural soils with beneficial bacteria or fungi, despite the exponentially growing number of studies that deal with plant growth-promoting (PGP) microbes since the 1990s (Finkel et al., 2017). Typically, these inoculants rarely establish viable populations in the soil environment, either because of inferior competitive abilities under natural conditions where resources are limited (de Souza et al., 2020), absence of preferred symbiotic partners (Hassani et al., 2018), or high sensitivity to predation, viral lysis or other multitrophic microbial interactions (Saleem and Moe, 2014). These general properties are all associated with an additional, rather cryptic set of traits controlling microbe-microbe interactions (thus conferring e.g. the ability of microbial inoculants to competitively establish viable populations in the rhizosphere), which is rarely considered in agroecological efforts. We do not intend to criticize or diminish the contribution of this line of research. Instead, we aim to 
stimulate a discussion to include a trait-based perspective that links management practices, crop traits, and microbial traits for sustainable agriculture that simultaneously maintain important agroecosystem processes.

A range of potentially useful microbial traits has been identified (Brbić et al., 2016; Fry et al., 2019; Green et al., 2008). In one recently published paper, a comprehensive list was generated that contained $>400$ microbial traits related to biogeochemistry, bioremediation, disturbance responses, antibiotic resistance, and virulence (Escalas et al., 2019). Overall, the number of databases that can be explored for microbial trait-based studies is rapidly expanding. Next to more generally applicable databases, such as KEGG, and the trait data linked to the examples indicated above, databases have been compiled on e.g. bacterial phenology traits (Madin et al. 2020 SciData). The knowledge base on fungal traits is also expanding. Generally applicable fungal traits have been reviewed and presented elsewhere (Aguilar-Trigueros et al., 2015) and the first fungal trait databases have emerged (Põlme et al., 2020; Zanne et al., 2020).

In table 2 we provide an overview of microbial traits that might be particularly relevant to functional responses and effects in agroecosystems (Table 1). Depending on the agricultural practice and its primary target (e.g. C balance, phosphorus availability, abatement of greenhouse gas emissions, or soil suppression), a first step might be to focus on the corresponding traits and monitor and model their distribution along with crop productivity. In the following sections, we review and discuss microbial trait-based approaches relevant to understand and steer particular agroecosystem functioning and services.

\section{Microbial traits related to soil carbon cycling and storage}


One central feature of soil microbial functioning is $\mathrm{C}$ mineralization, the conversion of complex organic compounds to inorganic $\mathrm{C}$ while converting and incorporating a variable portion of this $\mathrm{C}$ into microbial biomass and soil organic matter, a process that also releases mineral nutrients. The first step of $\mathrm{C}$ mineralization consists of hydrolytic enzymes that cut complex organic macromolecules into smaller compounds. The production of such hydrolases may thus be considered a key soil microbial trait for soil fertility and C cycling. Though the variety of hydrolases and the rate of release of hydrolases into the surrounding soil matrix can differ among microorganisms (Wilson, 2016), various hydrolases are quite unspecific and are shared by many soil microorganisms (Berlemont and Martiny, 2013). Consequently, changes in organic matter hydrolysis do not seem to be strongly related to changes in microbial community structure (T. Weedon et al., 2012). Nevertheless, the production of lignin peroxidases and related enzymes are coupled to the presence of particular clades of soil fungi and accordingly lignin degradation is controlled by fungi (Bugg et al., 2011). For this reason, the ratio of fungal to bacterial biomass has been used for a long time as a key proxy for soil fertility and activity (Bailey et al., 2002). Trait-based approaches could thus have an important added value here given that the fungal traits and the functional genes related to these traits along with their presence among fungal species are increasingly being uncovered (Treseder and Lennon, 2015).

In addition to $\mathrm{C}$ mineralization, soil $\mathrm{C}$ storage is an increasingly important aspect of soil functioning for agriculture. Indeed, agroecosystems often deplete soil C stocks as compared to unmanaged, natural ecosystems (Guo and Gifford, 2002). Therefore, efforts have been made to establish management options that increase soil organic $\mathrm{C}$ stocks, including crop rotation with 
cover crops, perennial grasses or legumes, straw and manure incorporation, and reduced tillage. However, the success of these measures is not always guaranteed (Bell et al., 2013; Syswerda et al., 2011). Microbial trait-based approaches have an important potential in this context since microorganisms are important drivers of the balance between $\mathrm{C}$ released to the atmosphere and that sequestered into the soil. For instance, ectomycorrhizal (ECM) fungi have specific traits that allow them to acquire and release more $C$, with more oxidative enzymes and much more external mycelium (Soudzilovskaia et al., 2015). In particular, it has been suggested that ECM fungi differ in the morphology and biochemistry of their hyphae. Firstly, rhizomorphic ECM fungi generate ephemeral mycelia with hyphae that easily decompose and recycle their biomass very efficiently resulting in a rapid turnover of ECM fungal biomass and reduced $\mathrm{C}$ sequestration. In contrast, ECM fungi that develop the diffuse exploration mycelia type recycle their tissues less efficiently which contributes more to the buildup of fungal necromass and thus contribute to $\mathrm{C}$ sequestration. Secondly, ECM fungi differ in the concentration of melanine and hyaline in their hyphae which results in different decomposition rates of fungal necromass (Fernandez and Kennedy, 2015). Together, these hyphal traits contribute to a different extent to soil C storage (Averill et al., 2014; Soudzilovskaia et al., 2019). Moreover, there is growing evidence for indirect impacts of mycorrhiza on C cycling, e.g. through impacts on plant litter quality (Fernandez and Kennedy, 2018) and its effects of competition among associated plant species. Recent work also suggested that microbial C use efficiency (CUE) is crucial for the balance of soil $\mathrm{C}$ cycling because it directly influences the input of $\mathrm{C}$ into the soil from microbial biomass and biomolecule buildup (Allison et al., 2010; Kallenbach et al., 2019). CUE actually corresponds to an integrative trait (or a functional trait cluster), and the CUE values measured 
at the individual cell level can have a CUE that is much higher than the community average. In a recent study, an ${ }^{18} \mathrm{O}$ labeling approach demonstrated that under long-term NPK fertilization (> 20 years), a common practice in agriculture, microbial CUE increased by over $50 \%$ due to higher microbial growth and lower specific respiration (Poeplau et al., 2019). Only half of the measured soil organic $\mathrm{C}$ stocks could be explained by organic $\mathrm{C}$ inputs from plant production. Hence $\mathrm{C}$ sequestration is not driven by plant inputs alone, but is also influenced by contributions from microbial anabolic processes. These observations suggest that microbial CUE could be a useful microbial trait that can help to better understand $C$ dynamics in agroecosystems. Agricultural management practices could for instance focus on changing contemporary microbial CUE in the long run to achieve increased soil C storage. However, the application of using and steering microbial CUE for improved soil quality is still not standardized (Geyer et al., 2018) and our understanding is still largely limited to predict the outcomes of different agricultural management practices on CUE under field conditions (Kallenbach et al., 2019).

\section{Microbial traits related to soil structure}

Soil aggregation is a process that is strongly connected to soil structure properties and associated soil function. Essentially, soil aggregation encompasses the complex structure and arrangement of pore spaces as key properties for soil biota and fertility (Lehmann et al., 2020). Macro and micro aggregates are to a large extent controlled by soil bacteria and fungi, with fungi playing a particularly important role in macro aggregation (Lehmann et al., 2017). Rillig and colleagues (2015) were among the first researchers to consider trait-based approaches as a promising tool to obtain a fundamental mechanistic understanding of soil 
aggregation from an organismal perspective. A systematic investigation of traits of numerous and highly diverse fungal species revealed pronounced differences in the capacity of different fungi to promote soil aggregation (Lehmann et al., 2020). These differences were closely associated with traits such as the density of mycelium growth -as morphological trait- and leucine aminopeptidase activity. Rillig and colleagues (2015) also found that mycelium water repellency and mycelium exudate quality have profound impacts on soil aggregation. Detailed knowledge on such organismal traits forms a basis to reliably predict changes in soil properties from fungal and also plant diversity shaped by environmental driver variables that are in turn affected by agricultural management practices. These predictions are urgently needed to move forward to a more sustainable agriculture, improve agricultural management practices and the increasingly required restoration of the environment.

Yet, there are still many remaining questions (Rillig et al., 2015), including: (i) What is the relative importance of plant and mycorrhizal fungal trait values in comparison to state variables such as soil characteristics in predicting soil aggregation? (ii) Does soil aggregation simultaneously affect plant and mycorrhizal fungal community processes providing integrative plant-soil feedbacks? In particular, to what extent does niche complementarity between plants and different fungal taxa result in soil aggregation stimulated through overproduction of relevant compounds by fungi and plant roots? (iii) Can specifically designed mycorrhizal fungal inocula and seed mixtures stimulate soil aggregation processes and improve agroecosystem restoration success, and based on which traits? Overall, more detailed insight into key mycorrhizal traits that affect soil aggregation may inform and guide agriculture management practices, including the PGP approach, to be more sustainable (Lehmann et al., 2020). This can 
also help identify the agroecosystems which are at high degradation risk and guide effective mitigation and restoration measures.

\section{Microbial traits related to plant nutrient acquisition}

Fungal traits play a key role in the context of plant nutrient acquisition. In particular, fungal association type has been identified as a key trait that allow for plant nutrient uptake strategies (Zanne et al., 2020). In this case, a prominent role is assigned to mycorrhizal fungi, directly associated with particular plant species. Both ectomycorrhizal fungi and arbuscular mycorrhizal fungi promote plant nutrition (e.g. phosphorous uptake, see Table 2), but in different ways (Tedersoo and Brundrett, 2017). While ectomycorrhizal fungi produce exudates with extracellular lytic enzymes that can break down organic compounds (Read et al., 2004), arbuscular mycorrhizal fungi generally lack these saprotrophic abilities and obtain nutrients mostly from inorganic compounds (Smith and Smith, 2011). As a consequence, different mycorrhizal types and their associated plant species (Barceló et al., 2019) prevail in different soil and climatic conditions.

Recently, plant-fungal interactions have been explicitly accounted for in soil organic matter models to create better predictions of, e.g., plant nitrogen (N) uptake (Brzostek et al., 2014). In this type of model, tradeoffs of active $\mathrm{N}$ uptake by mycorrhizal fungi were incorporated. In brief, two mycorrhizal fungal strategies were included based on the assumption that arbuscular mycorrhizal fungi are scavengers increasing the surface area-to-volume ratio of fungal roots and enzyme producers increasing the availability of $\mathrm{N}$ from OM.

\section{Microbial traits related to plant health and biocontrol}


Microbial traits can influence plant health, either indirectly when these traits hold a role in cascading effects on plant defense, and/or directly when microorganisms can limit or suppress attacks by some pathogens to plants. For instance, indirect effects are mediated by plant beneficial microorganisms that can influence the plant defenses against pests through an increase of plant vigor, an altered plant metabolism, the release of volatile organic compounds (VOC), modifications of the VOCs composition, and/or modifications of the soil chemical environment (Rasmann et al., 2017). As an example of direct effects, disease suppressive soils have been studied for decades, referring to the ability of soils to minimize the effects of virulent pathogens on a susceptible host in developing disease (Mazzola, 2002; Schlatter et al., 2017). Another study demonstrated that root-colonizing Paraburkholderia changed the plant traits with regards to growth and pathogen defense of Broccoli seedlings, but the level of change of these traits was strongly dependent on the specific bacterial strain and the Broccoli cultivar (Jeon et al., 2021). Such microbiome-associated plant phenotypes (Oyserman et al., 2021) are thus defined by particular microbes and represent a new trait category that may pave the way to a new view on plant traits in agroecosystems. Such microbiome-associated phenotypes also offer a way to account for eco-evolutionary feedbacks (as discussed above) that may arise from coevolution of hosts and their microbes (Oyserman et al., 2021). As another example, an endophytic consortium of Flavobacteria and Chitinophaga possesses disease-suppressive capabilities (Carrión et al., 2019). The researchers identified specific genomic functional traits represented by chitinase genes and several new biosynthetic gene clusters (Table 2). These traits could serve as a stepping stone to develop a monitoring tool for new management strategies that consider microbiome-associated phenotypes of the plant. The soil microbiome 
harbors a plethora of undiscovered functional traits that can help develop more sustainable agriculture. Plant breeders might thus consider a "back to the root" approach (Pérez-Jaramillo et al., 2016) to screen the microbiome-host holobiont of wild relatives of cultivated plants in their natural habitat to find and exploit both plant and microbial traits that can improve plant health (Cordovez et al., 2019).

\section{Microbial traits related to greenhouse gas emissions}

Besides the many services that agricultural soils provide, they also represent a significant source of greenhouse gases (GHG) (Paustian et al., 2016; Saunois et al., 2020). For example, agriculture contributes to more than $50 \%$ of the anthropogenic $\mathrm{N}_{2} \mathrm{O}$ emissions. Because denitrifiers have distinct traits important for net $\mathrm{N}_{2} \mathrm{O}$ production, ranging from resource use (Salles et al., 2009) to their capacity to produce vs. reduce $\mathrm{N}_{2} \mathrm{O}$ (Jones et al., 2014), trait-based approaches are appealing alternatives to better understand and manage $\mathrm{N}_{2} \mathrm{O}$ emissions from agroecosystems, as proposed by (Philippot and Hallin, 2011). An additional prominent example of the potential of microbial trait-based approaches regarding greenhouse gas emissions in agroecosystems concerns the emission of the potent greenhouse gas methane from rice agriculture, contributing approximately $11 \%$ to the total anthropogenic methane emissions (Saunois et al., 2020). Combined with the projected accelerating effects of increasing temperature and $\mathrm{CO}_{2}$ on rice associated GHG emissions (Bodelier and Steenbergh, 2014; Qian et al., 2020), the quest for high productivity rice with low climate impact is a model example for a plant-microbe trait-based approach with the goal to mitigate climate change (Paustian et al., 2016). The rice microbiome has been increasingly investigated in the quest for climate-smart and sustainable rice, searching for microbes with beneficial traits for growth and development 
of various parts of the rice plants (Edwards et al., 2015; Kim and Lee, 2020). In parallel, there has been a quest for rice varieties (breeding as well as genetically engineered) that can influence microbial traits and modulate belowground biogeochemistry towards lower methane production and higher oxidation (Su et al., 2015). Besides a range of abiotic parameters (e.g. hydrology), the emission of methane from rice paddies is mainly influenced by functional traits related to gas transport from soil to the atmosphere. In particular, $\mathrm{C}$ and oxygen availability around the roots are important factors affecting the activities of methanogenic Archaea and methanotrophic bacteria (Dean et al., 2018; Steenbergh et al., 2017). As such, an "empiricaltrait-based" approach works quite well because of the limited number of key taxa involved (Liechty et al., 2020) and wealth of knowledge already available on traits and environmental distribution of methanogens (Evans et al., 2019; Wen et al., 2017) and methanotrophs (Bodelier et al., 2019; Knief, 2015).

Of high relevance for trait-based approaches to abate methane emissions from rice soils are important recent discoveries of methane production under aerobic conditions (Angle et al., 2017) as well as oxygen tolerant methanogens (Angle et al., 2017; Lyu and Lu, 2018), potential novel methanogenic phyla (Evans et al., 2015), anaerobic methane oxidation (Guerrero-Cruz et al., 2018; Vaksmaa et al., 2017), metabolic versatility of methanotrophs (Farhan UI Haque et al., 2020) and novel methanotrophic lineages (Shen et al., 2021). All relevant knowledge on such traits and biogeochemical processes has not yet been incorporated in models predicting the emission of methane from rice paddies. This implies that the continuous cross-fertilization of phenotypic and genomic data will be essential for applying trait-based predictions of microbialdriven ecosystem processes. In addition, the focus on methanogens and methanotrophs has led 
to an oversight of the role played by the upstream fermentative taxa producing the "precursors" of methane. High methane emitting rice cultivars were demonstrated to have high abundances of such upstream fermenting taxa on and in rice roots (Liechty et al., 2020), indicating another "blind spot" in microbial traits involved in methane cycling.

A major challenge in applying trait-based approaches will be to predict the outcome of climate change and management practices on greenhouse gas emission as well as on interactions of the various taxa involved (Bodelier and Steenbergh, 2014). The outcome of interactive environmental effects or species interactions is difficult to predict and needs to be fed with experimental information, for example from meta-analyses of existing datasets (Zhou et al., 2020) or using computational approaches that asses metabolic overlap, based on metagenome data, thereby predicting potential beneficial or competitive interactions (Hester et al., 2019). However, next to predictions, the actual assessment of expressed traits in the environment will be crucial considering the strong influence of the environmental context. Stable isotope approaches have been developed to determine taxa-based in situ growth rates (Li et al., 2019) as well as taxa-based interactions (Daebeler et al., 2014). Models to bring in the spatial habitat context in the linking of traits to greenhouse gas emission will also allow new opportunities here (Ebrahimi and Or, 2017).

\section{Microbial traits related to drought stress resistance}

Biofilm traits can confer tolerance to drought stress and prevent soils from drying out, thereby potentially ameliorating environmental stress for plants. Biofilm production involves the release of exopolymeric substances (EPS) into the surrounding environment. It has been estimated that biofilms, which are made up of nucleic acids, proteins, and carbohydrates, 
constitute up to $1.5 \%$ of the soil OM pool (Chenu, 1995). Microorganisms often become embedded in this matrix, which can prevent cells from being washed away from high-quality microsites in the heterogeneous soil environment. Biofilm production can also influence soil structure and aggregation and may also contribute to the generally patchy distribution of microorganisms in the soil (Costa et al., 2018) which has important implications for a range of ecological and evolutionary processes. The three-dimensional structure of biofilms can protect cells from environmental stressors (e.g., metals, antibiotics, virus infection, etc.), and can facilitate lateral gene transfer events and cell-cell communication (Lee et al., 2014; Madsen et al., 2012; Solano et al., 2014). Biofilm production can be viewed as a response trait since biofilms can help bacteria contend with desiccation stress, which is common in soils that commonly undergo drying and rewetting cycles (Lennon and Lehmkuhl, 2016). This is because some biofilms have hydrophobic properties that alter local moisture conditions (Ophir and Gutnick, 1994). A comparative study of 50 strains of bacteria and fungi revealed that physiological performance along moisture gradients was correlated with the capacity to form biofilms, a trait which appears to be conserved at a coarse taxonomic scale (Lennon et al., 2012). Biofilm production can also be considered an effect trait, which means that it can alter the environment with implications for species interactions and ecosystem processes. In this way, biofilm production may be important for niche construction in soils. For example, in soils inoculated with a biofilm deficient strain, water potentials became more negative (drier) than soils inoculated with a biofilm-producing strain (Lennon and Lehmkuhl, 2016). This shows that biofilm production could be a trait important for understanding soil structure and resistance to drought, and trait-based approaches aimed at improving biofilm formation could thus offer 
opportunities for more sustainable agriculture in the face of climate change and increased frequency and intensity of drought events.

\section{Microbial traits related to heavy metal bioavailability in agroecosystems}

Coupled traits in plants and associated microbes can influence heavy metal bioavailability for crops, which can have major consequences for human health (Hou et al., 2020). As a model example, ingestion of toxic methylmercury ( $\mathrm{MeHg}$ ) via consumption of rice can be a major route of human exposure to this harmful contaminant (Wu et al., 2020; Zhao et al., 2020). This organic form of mercury $(\mathrm{Hg})$ is more toxic and also more prone to bioaccumulation compared to inorganic or elemental $\mathrm{Hg}$ and is biologically produced anaerobically by a plethora of taxonomically diverse bacteria and archaea, including those that use sulfate or ferric iron as electron acceptors, methanogens and fermenters (Peterson et al., 2020). Not all members of these metabolic guilds can transform inorganic $\mathrm{Hg}$ to $\mathrm{MeHg}$, but this functional trait is restricted to those populations that carry the hgcAB genes known to be centrally involved in the methylation process (Parks et al., 2013). This genome-encoded trait is not monophyletically distributed nor essential for organismal survival and propagation, and as of yet, we do not fully understand what benefits the trait could bring to the organisms. The characteristics of these habitats and the shuttling of energy and nutrients between plants and microbe form the basis for the coupling of traits across domains that may either prevent or enhance $\mathrm{Hg}$ accumulation in the rice grain. Root exudate profiles that select for $\mathrm{Hg}$ methylators lead to enhanced $\mathrm{Hg}$ uptake with increasing risks for harmful exposure, while root conditions that select for their non-methylating competitors do not. Additionally, the supporting microbial communities that feed the methylators with substrates play a role, calling for broad characterization not only of 
the organisms responsible for the $\mathrm{Hg}$ transformation itself but the entire microbial food web to study and control the process (Xu et al., 2019).

\section{Eco-phenotyping of plant-microbiome holobionts for improving cultivated plant selection}

\section{and assembling beneficial microbiomes}

As touched upon in the sections above, considering microbial traits relevant to specific functions and services at the level of microbial individuals and communities is often not sufficient, and interactions between plants and microbial communities are often highly important. One aspect of this is that plants are driving the assembly of their associated microbial communities and are therefore hosting a microbiome that is different from the surrounding environment (Philippot et al., 2013) but interestingly also vary between plant species or varieties (Lundberg et al., 2012; Patra et al., 2006). During the last decades, a growing body of literature showed that the plant microbiome is not simply a mere collection of microorganisms associated with the plant and that its importance for plant fitness is much greater than previously believed (Compant et al., 2019). Thus, not only the plant microbiome plays a role in nutrient availability and acquisition (Bonfante and Genre, 2010; Philippot et al., 2013) but it also provides other, hitherto overlooked services to its host related to the protection against biotic and abiotic stresses (de Vrieze, 2015). For instance, arbuscular mycorrhizal fungi can enhance stomatal conductance, leaf water potential as well as relative water content, therefore alleviating drought stress for plants (Augé et al., 2015; Duc et al., 2018). As stated above, plant-associated microorganisms can also trigger an induced systemic resistance response in their host, which enhances plant defense against a broad range of pathogens and plant-feeding insects (Pieterse et al., 2014). It has thus been proposed that plants should no longer be seen as standalone entities but as holobionts, i.e. 
multipartite entities formed by the host plant and its microbiome (Vandenkoornhuyse et al., 2015). The holobiont concept, which considers plant and associated microorganisms as a unit of selection, has led to a paradigm shift with several practical implications. In particular, crop domestication has traditionally focused only on the selection of plant traits such as yield components and lodging resistance without considering their microbiome while wild plants are co-evolving over time with their microbiome. As a consequence, domestication led to spectacular modifications of plant traits that are more advantageous or desirable for humans under prescribed agricultural conditions but sometimes with 'hidden' counter-selection of other traits that can be advantageous under e.g. less intensive agricultural practices (Cantarel et al., 2021). Domestication can thus have resulted in the loss of important traits required to assemble a beneficial and diverse microbiome (Bulgarelli et al., 2015; Pérez-Jaramillo et al., 2016). For example, microbial traits related to nutrient availability are less important for plants selected for agricultural systems characterized by high herbicide and fertilizer inputs, as exemplified by the lower contribution of arbuscular mycorrhizal fungi to wheat $\mathrm{P}$ nutrition in modern compared to old cultivars (Zhu et al., 2001).

With increasing environmental concern and global change, bringing microbes into plant breeding to reestablish beneficial associations that were undermined during plant domestication is of increasing interest (Gopal and Gupta, 2016; Mueller and Sachs, 2015; Pérez-Jaramillo et al., 2016; Wei and Jousset, 2017). In this perspective, the plant holobiont encompasses a broad range of microbial traits that have the potential to decrease the environmental impacts of food production for more sustainable agricultural systems. For example, selecting for microbial traits enhancing plant defense against pathogens through systemic acquired resistance or induced 
systemic resistance, as well as traits linked to production of compounds detrimental to plant pathogens such as the antibiotic 2,4-diacetylphloroglucinol, can help to decrease the need for external inputs of chemical pesticides (Velusamy et al., 2006). Other examples would be the selection of rhizospheric bacteria having the capacity to produce exopolysaccharide and form biofilms, hence improving soil aggregation and possibly $\mathrm{C}$ sequestration and plant resistance to drought stress (see section 8), or the selection of microbial traits responsible for modified root morphology and greater water acquisition possibly from deeper soil layers (Jochum et al., 2019). Breeding the crop microbiome to favor this type of traits has the potential to make crop production less vulnerable to climate change (e.g. higher crop drought resistance) and/or to mitigate the effects of agricultural systems on climate change (e.g. increased soil C sequestration, decreased GHG emissions). As an additional example, recent work showed that a landrace of maize growing in $\mathrm{N}$-depleted fields could produce a sugar-rich mucilage associated with aerial roots to recruit $\mathrm{N}$-fixing bacteria (Van Deynze et al., 2018). Breeding such traits offer the potential to reduce the reliance on $\mathrm{N}$ fertilizers for crop production.

Several studies have shown how plant domestication can select for rhizosphere or root microorganisms and microbial traits (Bulgarelli et al., 2015; Leff et al., 2017; Spor et al., 2020), and, it has been suggested that harnessing plant microbiomes for agricultural production might now be achievable (Sutherland et al., 2019). The manipulation/selection of complex microbial communities has for long not been tractable, but a range of technological advances such as high throughput screening of microorganisms, machine learning, and digital technologies have recently reinvigorated this field (Finkel et al., 2017). Large research infrastructures have recently emerged for phenotyping crop-microbe systems (e.g. the Netherlands Plant Eco-phenotyping 
Centre), while an increasing number of start-up companies screen, select, and assemble rhizospheric microbes based on their beneficial traits for plants. For instance, AgBiome has selected microorganisms with relevant traits to kill insect pests, fungal pathogens, and weeds, while Indigo Agriculture has selected microorganisms to make cotton plants more resistant under drought conditions (Sutherland et al., 2019). We are thus on the edge of a revolution for agriculture based on two pillars: (i) trait-based selection of rhizospheric microorganisms and (ii) elucidation of the rules of functionally programmable plant microbiome assembly.

\section{Eco-engineering of the soil microbiota through the use of plant ecotypes able to select for specific soil microbial traits or holobiont modules}

As a complement to the holistic approach presented above, another microbial trait-based approach for agro-ecosystems is the use of plant varieties or ecotypes able to influence specifically particular soil microbial traits, in essence, a plant-driven and targeted ecoengineering of the soil microbiota -or more generally of specific modules of the holobiont.

One example of this approach is the use of plants having the capacity to inhibit nitrifiers. It has been reported that the roots of some plant species or ecotypes exude specific compounds that can suppress over $90 \%$ of soil nitrification, a process called Biological Nitrification Inhibition, BNI (Subbarao et al., 2007; Subbarao et al., 2013). BNI generally targets soil microorganisms harboring ammonia monooxygenase (AMO) enzymes that render them able to perform the first enzymatic step of ammonia oxidation (Sun et al., 2016). Some plants with BNI capacity can also inhibit and depress microorganisms performing the second step of nitrification, i.e. nitrite oxidation (Laffite et al., 2020). Because soil nitrification is a major contributor to $\mathrm{N}$ loss in agricultural systems by nitrate leaching and denitrification coupled with emissions of gaseous $\mathrm{N}$ 
compounds, the use of cultivated plant species or varieties that can counter-select microbial traits such as those linked to nitrification (and that can efficiently use soil ammonium rather than nitrate) has huge potential to improve N-use efficiency of agricultural systems (Sun et al., 2016). Similarly, some plants can inhibit denitrifiers, a process called Biological Denitrification Inhibition, BDI (Bardon et al., 2018; Bardon et al., 2017). However, the practical use of plant species and varieties with $\mathrm{BDI}$ capacity to inhibit denitrifiers (and thus $\mathrm{N}$ losses and $\mathrm{N}_{2} \mathrm{O}$ emissions) in agricultural systems largely remains to be benchmarked and explored (but see Galland et al., 2019).

The cases above are emblematic examples of eco-engineering of (part of) the soil microbiota through the use of plant ecotypes. There are many other examples of selection or counterselection, thus offering many opportunities for fine-tuned, biologically sound eco-engineering of soil microbiota in agricultural lands. This of course includes recruitment of soil microorganisms with traits favorable to cope with nutrient limitation (Averill et al., 2019; Moreau et al., 2019). Breeding plants with such traits offer the potential to reduce the reliance on $\mathrm{N}$ fertilizers for crop production.

We consider that, too often, stakeholders from the farming sector tend to favor the manipulation of the targeted microbial functions either through inoculation of one or a few microorganisms that feature beneficial traits or through the application of specific compounds such as nitrification or denitrification inhibitors (Slangen and Kerkhoff, 1984). However, microbial inoculants generally do not maintain themselves in soil for an extended time (Mallon et al., 2015) and the application of chemicals is costly and does not allow for continuous delivery of the compounds during the plant growth period. We thus advocate that a more promising eco- 
engineering approach to shape soil microbiota is the systematic selection of cultivated plants able to select or counter-select specific microbial traits. This however requires renewing cultivated plant selection schemes by considering 'extended' and somewhat cryptic plant traits based on their influence on microbial traits (e.g. plant BNI or BDI capacity). For agronomists and plant breeders, this means evolving from a plant-oriented perspective to a plant-microbes perspective.

\section{Concluding remarks and perspectives}

Belowground soil life is recognized as a key contributor to agroecosystem functions and services. The application of the trait-based approach to agroecosystems is not the holy grail to make agroecosystems more sustainable but can likely help to generate a predictive framework and to tailor management strategies that accommodate both agricultural needs and critical ecosystem services.

Omics approaches are allowing insights into microbial functional traits at least indirectly, but the challenge will be to account for unknown interactions with covarying traits that might be critical to their actual phenotype (Prosser, 2015). For instance, trade-offs exist between the expression of virulence and tolerance of fungicides in plant pathogens (Dutta et al., 2021), which may offer an opportunity for developing sustainable disease management strategies. In addition, eco-evolutionary feedbacks are very likely in microbial systems, such as covarying traits that evolve in networks rather than individually in response to new environmental conditions. These networks may disintegrate and restructure under new environmental conditions, resulting in a phenotype different from the original one (Li et al., 2021). Finally, 
given the tight linkages between plant and associated microbiome, i.e. holobiont, we need to assess plant and microbial traits simultaneously.

A rather promising field of research would be -as suggested by Wood et al (2015)- to build a large-scale trait database with coordinated collection and aggregation of trait data in a universally accessible agricultural trait database for all species in agroecosystems, across taxa, farm management, and environmental conditions. Next to more generally applicable databases, such as KEGG, and the trait data linked to the examples indicated above, databases have been compiled on e.g. bacterial phenotypic traits (Madin et al., 2020). In addition, the knowledge base on fungal traits is expanding, with the launch of some first fungal trait databases (Põlme et al., 2020; Zanne et al., 2020). The development of these microbial trait databases might greatly promote the use of the different trait-based approaches reviewed above.

To develop more sustainable agricultural systems, we advocate for the selection and cultivation of plant species and varieties, using as deliberate selection targets the ability of plant to stimulate or inhibit soil microbes with specific functional traits or bundles of traits. It is indeed increasingly recognized that plant individuals can shape to some extent their environment, hence ultimately influencing their fitness (Abalos et al., 2019; Schweitzer et al., 2004). This ecological-evolutionary feedback loop is called 'niche construction' (Odling-Smee et al., 2003) and is often based on very specific plant-soil microbe interactions (Schweitzer et al., 2014). In the future, high-throughput screening of cultivated plant varieties or species and their wild relatives regarding their ability to stimulate or inhibit specific microbial functional types associated to, e.g., soil nutrient dynamics, can thus be envisaged to identify candidate varieties 
or species able to influence and reinforce agroecosystem services like soil fertility, climate regulation and water quality regulation, making agroecological systems more sustainable.

In this paper, we focused on the importance of belowground diversity as a primary target to achieve sustainable agriculture. However, the microbiome of the phyllosphere harbors a rich set of functional traits that can modulate plant physiological processes related to plant growth and health (Pattnaik et al., 2020; Remus-Emsermann et al., 2012). As such, phyllospheric traits may represent an overlooked part of the plant holobiont (Leveau, 2019; Vorholt, 2012) with significant impacts on the plant and ecosystem processes, but trait-based approaches targeting the phyllosphere microbiota is still an emerging field (Rosado et al., 2018).

Overall, trait-based approaches can provide a more mechanistic understanding of agrobiodiversity and ecosystem processes by considering the plant holobiont and its numerous covarying microbial and plant traits to support a systems-based approach to sustainable agroecosystems.

\section{Acknowledgments}

SMBK was funded by National Science Foundation of China (NSFC) International (Regional) Cooperation and Exchange Program (grant number 32050410288). XLR and LP were funded by the French Institute of Agriculture, Food and Environment Research (INRAE, ECODIV and AgroEcoSystems Departments, respectively). HPG was supported by the German Research Foundation (DFG) by the SPP Dynatrait project GR1540/30-1. SB was funded by the Swedish Research Council. This publication is publication number XXXX of the Netherlands Institute of Ecology (NIOO-KNAW). 


\section{Literature}

Abalos, D., van Groenigen, J.W., Philippot, L., Lubbers, I.M., and De Deyn, G.B., 2019. Plant traitbased approaches to improve nitrogen cycling in agroecosystems. J. Appl. Ecol. 56, 2454-2466.

Aguilar-Trigueros, C. A., Hempel, S., Powell, J.R., Anderson, I.C., Antonovics, J., Bergmann, J., Cavagnaro, T.R., Chen, B., Hart, M.M., Klironomos, J., Petermann, J.S., Verbruggen, E., Veresoglou, S.D., and Rillig, M.C., 2015. Branching out: Towards a trait-based understanding of fungal ecology. Fungal Biol. Rev. 29, 34-41.

Allison, S.D., and Gessner, M., 2012. A trait-based approach for modelling microbial litter decomposition. Ecol. Lett. 15, 1058-70.

Allison, S.D., Wallenstein, M.D., and Bradford, M.A., 2010. Soil-carbon response to warming dependent on microbial physiology. Nat. Geosci. 3, 336-340.

Alonso, C., Ramos-Cruz, D., and Becker, C., 2019. The role of plant epigenetics in biotic interactions. New Phytol. 221, 731-737.

Alvarez, C.R., Alvarez, R., Grigera, S., and Lavado, R.S., 1998. Associations between organic matter fractions and the active soil microbial biomass. Soil Biol. Biochem. 30, 767-773.

Angle, J.C., Morin, T. H., Solden, L.M., Narrowe, A.B., Smith, G.J., Borton, M.A., Rey-Sanchez, C., Daly, R.A., Mirfenderesgi, G., Hoyt, D.W., Riley, W.J., Miller, C.S., Bohrer, G., and Wrighton, K.C., 2017. Methanogenesis in oxygenated soils is a substantial fraction of wetland methane emissions. Nat. Comm. 8, 1567.

Augé, R.M., Toler, H.D., and Saxton, A.M., 2015. Arbuscular mycorrhizal symbiosis alters stomatal conductance of host plants more under drought than under amply watered conditions: a meta-analysis. Mycorrhiza 25, 13-24.

Averill, C., Bhatnagar, J.M., Dietze, M.C., Pearse, W.D., and Kivlin, S.N., 2019. Global imprint of mycorrhizal fungi on whole-plant nutrient economics. Proc. Natl. Acad. Sci. USA 116, 23163-23168.

Averill, C., Turner, B.L., and Finzi, A.C., 2014. Mycorrhiza-mediated competition between plants and decomposers drives soil carbon storage. Nature 505, 543-545. 
Backer, R., Rokem, J.S., Ilangumaran, G., Lamont, J., Praslickova, D., Ricci, E., Subramanian, S., and Smith, D.L., 2018. Plant Growth-Promoting Rhizobacteria: Context, Mechanisms of Action, and Roadmap to Commercialization of Biostimulants for Sustainable Agriculture. Front. Plant. Sci. 9, 9:1473.

Bailey, V., Smith, J. L., and Bolton, H., 2002. Bailey VL, Smith JL, Bolton H Jr.. Fungal-to-bacterial ratios in soils investigated for enhanced C sequestration. Soil Bio Biochem 34: 997-1007. Soil Biol.Biochem. 34, 997-1007.

Banerjee, S., Walder, F., Büchi, L., Meyer, M., Held, A.Y., Gattinger, A., Keller, T., Charles, R., and van der Heijden, M.G.A., 2019. Agricultural intensification reduces microbial network complexity and the abundance of keystone taxa in roots. ISME J. 13, 1722-1736.

Barceló, M., van Bodegom, P.M., and Soudzilovskaia, N.A., 2019. Climate drives the spatial distribution of mycorrhizal host plants in terrestrial ecosystems. J. Ecol. 107, 2564-2573.

Bardgett, R.D., and van der Putten, W.H., 2014. Belowground biodiversity and ecosystem functioning. Nature 515, 505-511.

Bardon, C., Misery, B., Florence, P., Poly, F., and Roux, X., 2018. Control of soil N cycle processes by Pteridium aquilinum and Erica cinerea in heathlands along a $\mathrm{pH}$ gradient. Ecosphere 9, e02426.

Bardon, C., Poly, F., Haichar, F. e. Z., Roux, X., Simon, L., Meiffren, G., Comte, G., Rouifed, S., and Florence, P., 2017. Biological denitrification inhibition (BDI) with procyanidins induces modification of root traits, growth and $\mathrm{N}$ status in Fallopia $\mathrm{x}$ bohemica. Soil Biol. Biochem. 107, 41-49.

Barot, S., Allard, V., Cantarel, A., Enjalbert, J., Gauffreteau, A., Goldringer, I., Lata, J.-C., Le Roux, X., Niboyet, A., and Porcher, E., 2017. Designing mixtures of varieties for multifunctional agriculture with the help of ecology. A review. Agron. Sustain. Dev. 37, 13.

Bell, L., Sparling, B., Tenuta, M., and Entz, M., 2013. Soil profile carbon and nutrient stocks under long-term conventional and organic crop and alfalfa-crop rotations and reestablished grassland. Agric. Ecosyst. Environ. 158, 156-163. 
Bender, S.F., Wagg, C., and van der Heijden, M.G.A., 2016. An underground revolution: biodiversity and soil ecological engineering for agricultural sustainability. Trends Ecol. Evol. 31, 440-452.

Berlemont, R., and Martiny, A.C., 2013. Phylogenetic distribution of potential cellulases in bacteria. Appl. Environ. Microbiol. 79, 1545-1554.

Bierne, H., Hamon, M., and Cossart, P., 2012. Epigenetics and Bacterial Infections. Cold Spring Harb. 2.

Blagodatskaya, E., and Kuzyakov, Y., 2013. Active microorganisms in soil: Critical review of estimation criteria and approaches. Soil Biol. Biochem. 67, 192-211.

Bodelier, P.L.E., Pérez, G., Veraart, A.J., and Krause, S.M.B., 2019. Methanotroph Ecology, Environmental Distribution and Functioning, in " Lee, E.Y. (Eds.) Methanotrophs: Microbiology Fundamentals and Biotechnological Applications". Springer International Publishing, Chambridge, pp. 1-38.

Bodelier, P.L.E., and Steenbergh, A.K., 2014. Interactions between methane and the nitrogen cycle in light of climate change. Curr. Opin. Environ. Sustain. 9-10, 26-36.

Bonfante, P., and Genre, A., 2010. Mechanisms underlying beneficial plant-fungus interactions in mycorrhizal symbiosis. Nat. Comm. 1, 48.

Brbić, M., Piškorec, M., Vidulin, V., Kriško, A., Šmuc, T., and Supek, F., 2016. The landscape of microbial phenotypic traits and associated genes. Nucleic Acids Res. 44, 10074-10090.

Brunetti, I., Tidball, M., and Couvet, D., 2019. Relationship between biodiversity and agricultural production. Nat. Res. Mod. 32, e12204.

Brzostek, E.R., Fisher, J.B., and Phillips, R.P., 2014. Modeling the carbon cost of plant nitrogen acquisition: Mycorrhizal trade-offs and multipath resistance uptake improve predictions of retranslocation. J. Geophys. Res. Biogeosci. 119, 1684-1697.

Bugg, T.D.H., Ahmad, M., Hardiman, E.M., and Rahmanpour, R., 2011. Pathways for degradation of lignin in bacteria and fungi. Nat. Prod. Rep. 28, 1883-1896.

Bulgarelli, D., Garrido-Oter, R., Münch, P., Weiman, A., Dröge, J., Pan, Y., McHardy, A., and Schulze-Lefert, P., 2015. Structure and Function of the Bacterial Root Microbiota in Wild and Domesticated Barley. Cell Host \& Microbe 17, 392-403. 
Cadotte, M.W., Carscadden, K., and Mirotchnick, N., 2011. Beyond species: functional diversity and the maintenance of ecological processes and services. J. Appl. Ecol. 48, 1079-1087. Cantarel, A.A.M., Allard, V., Andrieu, B., Barot, S., Enjalbert, J., Gervaix, J., Goldringer, I., Pommier, T., Saint-Jean, S., and Le Roux, X., 2021. Plant functional trait variability and trait syndromes among wheat varieties: the footprint of artificial selection. J. Exp. Bot. 72, 1166-1180.

Carrión, V.J., Perez-Jaramillo, J., Cordovez, V., Tracanna, V., de Hollander, M., Ruiz-Buck, D., Mendes, L.W., van Ijcken, W.F.J., Gomez-Exposito, R., Elsayed, S.S., Mohanraju, P., Arifah, A., van der Oost, J., Paulson, J.N., Mendes, R., van Wezel, G.P., Medema, M.H., and Raaijmakers, J.M., 2019. Pathogen-induced activation of disease-suppressive functions in the endophytic root microbiome. Science 366, 606-612.

Casadesús, J., and Low, D., 2006. Epigenetic Gene Regulation in the Bacterial World. Microbiol. Mol. Biol. Rev. 70, 830-856.

Chenu, C., 1995. Extracellular Polysaccharides: An interface Between Microorganisms and Soil Constituents, in: Huang, P.M. (Eds.), Environmental Impacts of Soil Component Interactions: Land Quality, Natural and Anthropogenic Organics, Volume I. CRC Press, Boca Raton, pp. 217-233.

Compant, S., Samad, A., Faist, H., and Sessitsch, A., 2019. A review on the plant microbiome: Ecology, functions, and emerging trends in microbial application. J. Adv. Res. 19, 29-37. Cooke, R.S.C., Bates, A.E., and Eigenbrod, F., 2019. Global trade-offs of functional redundancy and functional dispersion for birds and mammals. Glob. Ecol. Biogeogr. 28, 484-495.

Cordovez, V., Dini-Andreote, F., Carrión, V.J., and Raaijmakers, J.M., 2019. Ecology and Evolution of Plant Microbiomes. Annu. Rev. Microbiol. 73, 69-88.

Cordovez, V., Schop, S., Hordijk, K., Dupré de Boulois, H., Coppens, F., Hanssen, I., Raaijmakers, J.M., and Carrión, V.J., 2018. Priming of Plant Growth Promotion by Volatiles of RootAssociated Microbacterium spp. Appl. Environ. Microbiol. 84 : e01865-18.

Costa, O.Y.A., Raaijmakers, J.M., and Kuramae, E.E., 2018. Microbial Extracellular Polymeric Substances: Ecological Function and Impact on Soil Aggregation. Front. Microbiol. 9:1636. 
Daebeler, A., Bodelier, P., Zheng, Y., Hefting, M., Jia, Z., and Laanbroek, H., 2014. Interactions between Thaumarchaea, Nitrospira and methanotrophs modulate autotrophic nitrification in volcanic grassland soil. ISME J. 8, 2397-2410.

Dainese, M., Martin, E.A., Aizen, M.A., Albrecht, M., Bartomeus, I., Bommarco, R., Carvalheiro, L.G., Chaplin-Kramer, R., Gagic, V., Garibaldi, L.A., Ghazoul, J., Grab, H., Jonsson, M., Karp, D.S., Kennedy, C.M., Kleijn, D., Kremen, C., Landis, D.A., Letourneau, D.K., Marini, L., Poveda, K., Rader, R., Smith, H.G., Tscharntke, T., Andersson, G.K.S., Badenhausser, I., Baensch, S., Bezerra, A.D.M., Bianchi, F.J.J.A., Boreux, V., Bretagnolle, V., CaballeroLopez, B., Cavigliasso, P., Ćetković, A., Chacoff, N.P., Classen, A., Cusser, S., da Silva e Silva, F.D., de Groot, G.A., Dudenhöffer, J. H., Ekroos, J., Fijen, T., Franck, P., Freitas, B. M., Garratt, M.P.D., Gratton, C., Hipólito, J., Holzschuh, A., Hunt, L., Iverson, A.L., Jha, S., Keasar, T., Kim, T.N., Kishinevsky, M., Klatt, B.K., Klein, A.-M., Krewenka, K.M., Krishnan, S., Larsen, A.E., Lavigne, C., Liere, H., Maas, B., Mallinger, R.E., Martinez Pachon, E., Martínez-Salinas, A., Meehan, T.D., Mitchell, M.G.E., Molina, G.A.R., Nesper, M., Nilsson, L., Rourke, M.E., Peters, M.K., Plećaš, M., Potts, S.G., Ramos, D.d.L., Rosenheim, J.A., Rundlöf, M., Rusch, A., Sáez, A., Scheper, J., Schleuning, M., Schmack, J.M., Sciligo, A.R., Seymour, C., Stanley, D.A., Stewart, R., Stout, J.C., Sutter, L., Takada, M.B., Taki, H., Tamburini, G., Tschumi, M., Viana, B.F., Westphal, C., Willcox, B.K., Wratten, S.D., Yoshioka, A., Zaragoza-Trello, C., Zhang, W., Zou, Y., et al., 2019. A global synthesis reveals biodiversity-mediated benefits for crop production. Sci. Adv. 5, eaax0121. De Bie, T., De Meester, L., Brendonck, L., Martens, K., Goddeeris, B., Ercken, D., Hampel, H., Denys, L., Vanhecke, L., Van der Gucht, K., Van Wichelen, J., Vyverman, W., and Declerck, S. A. J., 2012. Body size and dispersal mode as key traits determining metacommunity structure of aquatic organisms. Ecol. Lett. 15, 740-747.

de Souza, R.S.C., Armanhi, J.S.L., and Arruda, P., 2020. From Microbiome to Traits: Designing Synthetic Microbial Communities for Improved Crop Resiliency. Front. Plant Sci. 11. de Vrieze, J., 2015. The littlest farmhands. Science 349, 680-683.

Dean, J.F., Middelburg, J.J., Röckmann, T., Aerts, R., Blauw, L.G., Egger, M., Jetten, M.S.M., de Jong, A.E.E., Meisel, O.H., Rasigraf, O., Slomp, C.P., in't Zandt, M.H., and Dolman, A.J., 
2018. Methane Feedbacks to the Global Climate System in a Warmer World. Rev. Geophys. 56, 207-250.

Díaz, S., Lavorel, S., de Bello, F., Quétier, F., Grigulis, K., and Robson, T.M., 2007. Incorporating plant functional diversity effects in ecosystem service assessments. Proc. Natl. Acad. Sci. USA 104, 20684-20689.

Dobzhansky, T., 1950. Heredity, environment, and evolution. Science 111, 161-166.

Dornbush, M.E., and von Haden, A.C., 2017. Chapter 8 - Intensified Agroecosystems and Their Effects on Soil Biodiversity and Soil Functions, in Al-Kaisi, M.M. and Lowery, B. (Eds.), Soil Health and Intensification of Agroecosytems. Academic Press, Watham, p. 173-193.

Duc, N.H., Csintalan, Z., and Posta, K., 2018. Arbuscular mycorrhizal fungi mitigate negative effects of combined drought and heat stress on tomato plants. Plant Physiol. Biochem. $132,297-307$.

Duca, D., Lorv, J., Patten, C.L., Rose, D., and Glick, B.R., 2014. Indole-3-acetic acid in plantmicrobe interactions. Antonie Van Leeuwenhoek 106, 85-125.

Dutta, A., Hartmann, F.E., Francisco, C.S., McDonald, B.A., and Croll, D., 2021. Mapping the adaptive landscape of a major agricultural pathogen reveals evolutionary constraints across heterogeneous environments. ISME J. 15, 1402-1419.

Ebrahimi, A., and Or, D., 2017. Mechanistic modeling of microbial interactions at pore to profile scale resolve methane emission dynamics from permafrost soil. J. Geophys. Res. Biogeosci. 122, 1216-1238.

Edwards, J., Johnson, C., Santos-Medellín, C., Lurie, E., Podishetty, N.K., Bhatnagar, S., Eisen, J. A., and Sundaresan, V., 2015. Structure, variation, and assembly of the root-associated microbiomes of rice. Proc. Natl. Acad. Sci. USA 112, E911-E920.

Escalas, A., Hale, L., Voordeckers, J.W., Yang, Y., Firestone, M.K., Alvarez-Cohen, L., and Zhou, J., 2019. Microbial functional diversity: From concepts to applications. Ecol. Evol. 9, 1200012016.

Evans, P., Boyd, J., Leu, A., Woodcroft, B., Parks, D., Philip, H., and Tyson, G., 2019. An evolving view of methane metabolism in the Archaea. Nat. Rev. Microbiol. 17, 219-232. 
Evans, P.N., Parks, D. H., Chadwick, G.L., Robbins, S.J., Orphan, V.J., Golding, S.D., and Tyson, G.W., 2015. Methane metabolism in the archaeal phylum Bathyarchaeota revealed by genome-centric metagenomics. Science 350, 434-438.

FAOSTAT, 2021. Food and agricultural data. http://www.fao.org/faostat/en/\#search/cite, accessed June 17, 2021.

Farhan UI Haque, M., Xu, H.J., Murrell, J.C., and Crombie, A., 2020. Facultative methanotrophs diversity, genetics, molecular ecology and biotechnological potential: a mini-review. Microbiology (Reading) 166, 894-908.

Fernandez, C.W., and Kennedy, P.G., 2015. Moving beyond the black-box: fungal traits, community structure, and carbon sequestration in forest soils. New Phytol. 205, 13781380.

Fernandez, C.W., and Kennedy, P.G., 2018. Melanization of mycorrhizal fungal necromass structures microbial decomposer communities. J. Ecol. 106, 468-479.

Fierer, N., 2017. Embracing the unknown: disentangling the complexities of the soil microbiome. Nat. Rev. Microbiol. 15, 579-590.

Fierer, N., Bradford, M.A., and Jackson, R.B., 2007. Toward an ecological classification of soil bacteria. Ecology 88, 1354-1364.

Finkel, O. M., Castrillo, G., Herrera Paredes, S., Salas González, I., and Dangl, J.L., 2017. Understanding and exploiting plant beneficial microbes. Curr. Opin. Plant. Biol. 38, 155163.

Foley, J.A., Defries, R., Asner, G. P., Barford, C., Bonan, G., Carpenter, S.R., Chapin, F.S., Coe, M.T., Daily, G.C., Gibbs, H.K., Helkowski, J.H., Holloway, T., Howard, E.A., Kucharik, C.J., Monfreda, C., Patz, J.A., Prentice, I.C., Ramankutty, N., and Snyder, P.K., 2005. Global Consequences of Land Use. Science 309, 570-574.

Fry, E.L., De Long, J.R., Álvarez Garrido, L., Alvarez, N., Carrillo, Y., Castañeda-Gómez, L., Chomel, M., Dondini, M., Drake, J.E., Hasegawa, S., Hortal, S., Jackson, B.G., Jiang, M., Lavallee, J. M., Medlyn, B.E., Rhymes, J., Singh, B.K., Smith, P., Anderson, I.C., Bardgett, R.D., Baggs, E.M., and Johnson, D., 2019. Using plant, microbe, and soil fauna traits to improve the predictive power of biogeochemical models. Methods Ecol. Evol. 10, 146-157. 
Fussmann, G.F., Loreau, M., and Abrams, P.A., 2007. Eco-evolutionary dynamics of communities and ecosystems. Funct. Ecol. 21, 465-477.

Galland, W., Florence, P., Burlet, A., Mathieu, C., Nardy, M., Poussineau, S., Blazère, L., Gervaix, J., Puijalon, S., Simon, L., and Haichar, F.e.Z., 2019. Biological denitrification inhibition (BDI) in the field: A strategy to improve plant nutrition and growth. Soil Biol. Biochem. 136, 107513.

Garnica, S., Rosenstein, R., and Schön, M.E., 2020. Belowground fungal community diversity, composition and ecological functionality associated with winter wheat in conventional and organic agricultural systems. PeerJ 8, e9732.

Geyer, K., Dijkstra, P., Sinsabaugh, R., and Frey, S., 2018. Clarifying the interpretation of carbon use efficiency in soil through methods comparison. Soil Biol. Biochem. 128, 79-88.

Gogarten, J. P., Doolittle, W.F., and Lawrence, J.G., 2002. Prokaryotic Evolution in Light of Gene Transfer. Mol. Biol. Evol. 19, 2226-2238.

Gopal, M., and Gupta, A., 2016. Microbiome Selection Could Spur Next-Generation Plant Breeding Strategies. Front. Microbiol. 7, 7:1971.

Govaert, L., Fronhofer, E.A., Lion, S., Eizaguirre, C., Bonte, D., Egas, M., Hendry, A.P., De Brito Martins, A., Melián, C.J., Raeymaekers, J.A.M., Ratikainen, I.I., Saether, B.-E., Schweitzer, J.A., and Matthews, B., 2018. Eco-evolutionary feedbacks-Theoretical models and perspectives. Funct. Ecol. 33, 13-30.

Green, J.L., Bohannan, B.J.M., and Whitaker, R.J., 2008. Microbial biogeography: From taxonomy to traits. Science 320, 1039-1043.

Grime, J. P., 1974. Vegetation classification by reference to strategies. Nature 250, 26-31.

Guerrero-Cruz, S., Cremers, G., van Alen, T.A., Op den Camp, H.J.M., Jetten, M.S.M., Rasigraf, O., and Vaksmaa, A., 2018. Response of the Anaerobic Methanotroph "Candidatus Methanoperedens nitroreducens" to Oxygen Stress. Appl. Environ. Microbiol. 84, e01832-18.

Guo, L.B., and Gifford, R.M., 2002. Soil carbon stocks and land use change: a meta analysis. Glob. Chang. Biol. 8, 345-360. 
Harbort, C.J., Hashimoto, M., Inoue, H., Niu, Y., Guan, R., Rombolà, A.D., Kopriva, S., Voges, M. J.E.E.E., Sattely, E.S., Garrido-Oter, R., and Schulze-Lefert, P., 2020. Root-Secreted Coumarins and the Microbiota Interact to Improve Iron Nutrition in Arabidopsis. Cell Host \& Microbe 28, 825-837.e6.

Hassani, M.A., Durán, P., and Hacquard, S., 2018. Microbial interactions within the plant holobiont. Microbiome 6, 58.

Herrel, A., Joly, D., and Danchin, E., 2020. Epigenetics in ecology and evolution. Funct. Ecol. 34, 381-384.

Hester, E.R., Jetten, M.S.M., Welte, C.U., and Lücker, S., 2019. Metabolic Overlap in Environmentally Diverse Microbial Communities. Front. Genet. 10, 10:989.

Ho, A., Kerckhof, F.-M., Luke, C., Reim, A., Krause, S., Boon, N., and Bodelier, P.L.E., 2013. Conceptualizing functional traits and ecological characteristics of methane-oxidizing bacteria as life strategies. Environ. Microbiol. Rep. 5, 335-345.

Hou, D., O’Connor, D., Igalavithana, A.D., Alessi, D.S., Luo, J., Tsang, D.C.W., Sparks, D.L., Yamauchi, Y., Rinklebe, J., and Ok, Y.S., 2020. Metal contamination and bioremediation of agricultural soils for food safety and sustainability. Nat. Rev. Earth Environ. 1, 366381.

Jeon, J.-S., Carreno-Quintero, N., van Eekelen, H.D.L.M., De Vos, R.C.H., Raaijmakers, J.M., and Etalo, D.W., 2021. Impact of root-associated strains of three Paraburkholderia species on primary and secondary metabolism of Brassica oleracea. Sci. Rep. 11, 2781.

Jochum, M.D., McWilliams, K.L., Borrego, E.J., Kolomiets, M.V., Niu, G., Pierson, E.A., and Jo, Y. K., 2019. Bioprospecting Plant Growth-Promoting Rhizobacteria That Mitigate Drought Stress in Grasses. Front. Microbiol. 10, 10:2106.

Johansson, J.F., Paul, L.R., and Finlay, R.D., 2004. Microbial interactions in the mycorrhizosphere and their significance for sustainable agriculture. FEMS Microbiol. Ecol. 48, 1-13.

Jones, C.M., Spor, A., Brennan, F.P., Breuil, M.-C., Bru, D., Lemanceau, P., Griffiths, B., Hallin, S., and Philippot, L., 2014. Recently identified microbial guild mediates soil $\mathrm{N}_{2} \mathrm{O}$ sink capacity. Nat. Clim. Chang. 4, 801-805. 
Kalia, V.C., Raju, S.C., and Purohit, H.J., 2011. Genomic analysis reveals versatile organisms for quorum quenching enzymes: acyl-homoserine lactone-acylase and -lactonase. Open Microbiol. 5, 1-13.

Kallenbach, C.M., Wallenstein, M.D., Schipanksi, M.E., and Grandy, A.S., 2019. Managing Agroecosystems for Soil Microbial Carbon Use Efficiency: Ecological Unknowns, Potential Outcomes, and a Path Forward. Front. Microbiol. 10, 10:1146.

Kearns, P.J., and Shade, A., 2018. Trait-based patterns of microbial dynamics in dormancy potential and heterotrophic strategy: case studies of resource-based and post-press succession. ISME J. 12, 2575-2581.

Kempes, C.P., van Bodegom, P.M., Wolpert, D., Libby, E., Amend, J., and Hoehler, T., 2017. Drivers of Bacterial Maintenance and Minimal Energy Requirements. Front. Microbiol. 8, 8:31.

Kibblewhite, M.G., Ritz, K., and Swift, M.J., 2008. Soil health in agricultural systems. Philos. Trans. R. Soc. Lond., B, Biol. Sci. 363, 685-701.

Kim, H., and Lee, Y.-H., 2020. The Rice Microbiome: A Model Platform for Crop Holobiome. Phytobiomes J. 4, 5-18.

Knief, C., 2015. Diversity and habitat preferences of cultivated and uncultivated aerobic methanotrophic bacteria evaluated based on $p m o A$ as molecular marker. Front. Microbiol. 6, 6:1346.

Krause, S., Le Roux, X., Niklaus, P.A., Bodegom, P.V., Lennon, J.T., Bertilsson, S., Grossart, H.-P., Philippot, L., and Bodelier, P., 2014a. Trait-based approaches for understanding microbial biodiversity and ecosystem functioning. Front. Microbiol. 5, 5:251.

Krause, S., van Bodegom, P.M., Cornwell, W.K., and Bodelier, P.L.E., 2014b. Weak phylogenetic signal in physiological traits of methane-oxidizing bacteria. J. Evol. Biol. 27, 1240-1247.

Krause, S.M.B., Meima-Franke, M., Veraart, A. J., Ren, G., Ho, A., and Bodelier, P.L.E., 2018. Environmental legacy contributes to the resilience of methane consumption in a laboratory microcosm system. Sci. Rep. 8, 8862.

Kuo, V., Lehmkuhl, B.K., and Lennon, J.T., 2021. Resuscitation of the microbial seed bank alters plant-soil interactions. Mol. Ecol. 30, 2905-2914. 
Laffite, A., Florio, A., Andrianarisoa, K.S., Creuze des Chatelliers, C., Schloter-Hai, B., Ndaw, S. M., Periot, C., Schloter, M., Zeller, B., Poly, F., and Le Roux, X., 2020. Biological inhibition of soil nitrification by forest tree species affects Nitrobacter populations. Environ. Microbiol. 22, 1141-1153.

Lajoie, G., and Kembel, S.W., 2019. Making the Most of Trait-Based Approaches for Microbial Ecology. Trends. Microbiol. 27, 814-823.

Lau, J. A., and Lennon, J.T., 2012. Rapid responses of soil microorganisms improve plant fitness in novel environments. Proc Natl Acad Sci USA 109, 14058-14062.

Lavorel, S., and Garnier, E., 2002. Predicting changes in community composition and ecosystem functioning from plant traits: revisiting the Holy Grail. Funct. Ecol. 16, 545-556.

Le Roux, X., Bouskill, N.J., Niboyet, A., Barthes, L., Dijkstra, P., Field, C.B., Hungate, B.A., Lerondelle, C., Pommier, T., Tang, J., Terada, A., Tourna, M., and Poly, F., 2016. Predicting the Responses of Soil Nitrite-Oxidizers to Multi-Factorial Global Change: A Trait-Based Approach. Front. Microbiol. 7, 7:628.

Lee, K.W.K., Periasamy, S., Mukherjee, M., Xie, C., Kjelleberg, S., and Rice, S.A., 2014. Biofilm development and enhanced stress resistance of a model, mixed-species community biofilm. ISME J. 8, 894-907.

Leff, J.W., Lynch, R.C., Kane, N.C., and Fierer, N., 2017. Plant domestication and the assembly of bacterial and fungal communities associated with strains of the common sunflower, Helianthus annuus. New. Phytol. 214, 412-423.

Lehmann, A., Zheng, W., and Rillig, M.C., 2017. Soil biota contributions to soil aggregation. Nat. Ecol. Evol. 1, 1828-1835.

Lehmann, A., Zheng, W., Ryo, M., Soutschek, K., Roy, J., Rongstock, R., Maaß, S., and Rillig, M.C., 2020. Fungal Traits Important for Soil Aggregation. Front. Microbiol. 10, 10:2904.

Lennon, J.T., Aanderud, Z.T., Lehmkuhl, B.K., and Schoolmaster, D.R., Jr., 2012. Mapping the niche space of soil microorganisms using taxonomy and traits. Ecology 93, 1867-79.

Lennon, J.T., and Jones, S.E., 2011. Microbial seed banks: the ecological and evolutionary implications of dormancy. Nat. Rev. Microbiol. 119, 119-130. 
Lennon, J.T., and Lehmkuhl, B.K., 2016. A trait-based approach to bacterial biofilms in soil. Environ. Microbiol.18, 2732-2742.

Leveau, J.H., 2019. A brief from the leaf: latest research to inform our understanding of the phyllosphere microbiome. Curr. Opin. Microbiol. 49, 41-49.

Li, E., Ryo, M., Kowalchuk, G.A., Bakker, P.A.H.M., and Jousset, A., 2021. Rapid evolution of trait correlation networks during bacterial adaptation to the rhizosphere. Evolution 75, 12181229.

Li, J., Mau, R. L., Dijkstra, P., Koch, B.J., Schwartz, E., Liu, X.-J. A., Morrissey, E.M., Blazewicz, S.J., Pett-Ridge, J., Stone, B.W., Hayer, M., and Hungate, B.A., 2019. Predictive genomic traits for bacterial growth in culture versus actual growth in soil. ISME J. 13, 2162-2172.

Liechty, Z., Santos-Medellín, C., Edwards, J., Nguyen, B., Mikhail, D., Eason, S., Phillips, G., and Sundaresan, V., 2020. Comparative Analysis of Root Microbiomes of Rice Cultivars with High and Low Methane Emissions Reveals Differences in Abundance of Methanogenic Archaea and Putative Upstream Fermenters. mSystems 5, e00897-19.

Litchman, E., Klausmeier, C.A., Schofield, O.M., and Falkowski, P.G., 2007. The role of functional traits and trade-offs in structuring phytoplankton communities: scaling from cellular to ecosystem level. Ecol. Lett. 10, 1170-81.

Lundberg, D., Lebeis, S., Herrera Paredes, S., Yourstone, S., Gehring, J., Malfatti, S., Tremblay, J., Engelbrektson, A., Kunin, V., Rio, T., Edgar, R., Eickhorst, T., Ley, R., Philip, H., Tringe, S., and Dangl, J., 2012. Defining the core Arabidopsis thaliana root microbiome. Nature 488, 86-90.

Lyu, Z., and Lu, Y., 2018. Metabolic shift at the class level sheds light on adaptation of methanogens to oxidative environments. ISME J. 12, 411-423.

Ma, B., Zhou, X., Zhang, Q., Qin, M., Hu, L., Yang, K., Xie, Z., Ma, W., Chen, B., Feng, H., Liu, Y., Du, G., Ma, X., and Le Roux, X., 2019. How do soil micro-organisms respond to N, P and NP additions? Application of the ecological framework of (co-)limitation by multiple resources. J. Ecol.107, 2329-2345.

Madin, J. S., Nielsen, D.A., Brbic, M., Corkrey, R., Danko, D., Edwards, K., Engqvist, M.K.M., Fierer, N., Geoghegan, J. L., Gillings, M., Kyrpides, N.C., Litchman, E., Mason, C.E., 
Moore, L., Nielsen, S.L., Paulsen, I.T., Price, N.D., Reddy, T.B.K., Richards, M.A., Rocha, E.P.C., Schmidt, T.M., Shaaban, H., Shukla, M., Supek, F., Tetu, S.G., Vieira-Silva, S., Wattam, A.R., Westfall, D.A., and Westoby, M., 2020. A synthesis of bacterial and archaeal phenotypic trait data. Scientific Data 7, 170.

Madsen, J.S., Burmølle, M., Hansen, L.H., and Sørensen, S.J., 2012. The interconnection between biofilm formation and horizontal gene transfer. FEMS Immunol. Med. Microbiol. 65, 183-95.

Malik, A.A., Martiny, J.B.H., Brodie, E.L., Martiny, A.C., Treseder, K.K., and Allison, S.D., 2020. Defining trait-based microbial strategies with consequences for soil carbon cycling under climate change. ISME J. 14, 1-9.

Mallon, C.A., Poly, F., Le Roux, X., Marring, I., van Elsas, J.D., and Salles, J.F., 2015. Resource pulses can alleviate the biodiversity-invasion relationship in soil microbial communities. Ecology 96, 915-926.

Manzoni, S., Taylor, P., Richter, A., Porporato, A., and Ågren, G.I., 2012. Environmental and stoichiometric controls on microbial carbon-use efficiency in soils. New Phytol. 196, 7991.

Margulis, L., 1990. Words as battle cries--symbiogenesis and the new field of endocytobiology. Bioscience 40, 673-677.

Mariotte, P., Mehrabi, Z., Bezemer, T.M., De Deyn, G.B., Kulmatiski, A., Drigo, B., Veen, G.F., van der Heijden, M.G.A., and Kardol, P., 2018. Plant-Soil Feedback: Bridging Natural and Agricultural Sciences. Trends Ecol. Evol. 33, 129-142.

Martiny, A.C., Treseder, K., and Pusch, G., 2012. Phylogenetic conservatism of functional traits in microorganisms. ISME Journal 7, 830-838.

Martiny, J.B.H., Jones, S.E., Lennon, J.T., and Martiny, A.C., 2015. Microbiomes in light of traits: A phylogenetic perspective. Science 350, aac9323.

Matson, P.A., Parton, W., Power, A., and Swift, M.J., 1997. Agricultural Intensification and Ecosystem Properties. Science, New York, N.Y.) 277, 504-509.

Mazzola, M., 2002. Mechanisms of natural soil suppressiveness to soilborne diseases. Antonie Van Leeuwenhoek 81, 557-564. 
Moreau, D., Bardgett, R.D., Finlay, R.D., Jones, D.L., and Philippot, L., 2019. A plant perspective on nitrogen cycling in the rhizosphere. Funct. Ecol. 33, 540-552.

Mueller, U.G., and Sachs, J.L., 2015. Engineering Microbiomes to Improve Plant and Animal Health. Trends Microbiol 23, 606-617.

Neal, A.L., Rossmann, M., Brearley, C., Akkari, E., Guyomar, C., Clark, I.M., Allen, E., and Hirsch, P.R., 2017. Land-use influences phosphatase gene microdiversity in soils. Environ. Microbiol.19, 2740-2753.

Nelson, M.B., Martiny, A.C., and Martiny, J.B.H., 2016. Global biogeography of microbial nitrogen-cycling traits in soil. Proc. Natl. Acad. Sci. USA 113, 8033-8040.

Odling-Smee, F.J., Laland, K.N., and Feldman, M.W., 2003. Niche Construction The Neglected Process in Evolution, Monographs in Population Biology, 37, Princeton University Press, Princton.

Ophir, T., and Gutnick, D.L., 1994. A Role for Exopolysaccharides in the Protection of Microorganisms from Desiccation. Appl. Environ. Microbiol.60, 740-745.

Ormeño-Orrillo, E., Hungria, M., and Martínez-Romero, E., 2013. Dinitrogen-Fixing Prokaryotes, in Rosenberg, E., DeLong, E.F., Lory, S., Stackebrandt, E., Thompson, F. (Eds.), The Prokaryotes. Springer, Berlin, Heidelberg, pp. 427-451.

Ortiz, A.M., Ortiz, D., Outhwaite, C., Dalin, C., and Newbold, T., 2021. A review of the interactions between biodiversity, agriculture, climate change, and international trade: research and policy priorities. One Earth 4, 88-101.

Oyserman, B.O., Cordovez, V., Flores, S.S., Leite, M.F.A., Nijveen, H., Medema, M.H., and Raaijmakers, J.M., 2021. Extracting the GEMs: Genotype, Environment, and Microbiome Interactions Shaping Host Phenotypes. Front. Microbiol. 11, 11:574053.

Parks, J.M., Johs, A., Podar, M., Bridou, R., Hurt, R.A., Jr., Smith, S.D., Tomanicek, S.J., Qian, Y., Brown, S.D., Brandt, C.C., Palumbo, A.V., Smith, J.C., Wall, J.D., Elias, D.A., and Liang, L., 2013. The genetic basis for bacterial mercury methylation. Science 339, 1332-1335.

Patra, A.K., Abbadie, L., Clays-Josserand, A., Degrange, V., Grayston, S.J., Guillaumaud, N., Loiseau, P., Louault, F., Mahmood, S., Nazaret, S., Philippot, L., Poly, F., Prosser, J.I., and Roux, X.L., 2006. Effects of management regime and plant species on the enzyme 
activity and genetic structure of $\mathrm{N}$-fixing, denitrifying and nitrifying bacterial communities in grassland soils. Environ. Microbiol. 8, 1005-1016.

Pattnaik, S.S., Paramanantham, P., and Busi, S., 2020. Agricultural Importance of Phyllosphere Microbiome, in Srivastava, A.K, Kashyap, P.L., Srivastava, M., The Plant Microbiome in Sustainable Agriculture. John Wiley \& Sons, Hoboken, pp. 119-139.

Paustian, K., Lehmann, J., Ogle, S., Reay, D., Robertson, G.P., and Smith, P., 2016. Climate-smart soils. Nature $532,49-57$.

Pe'er, G., Zinngrebe, Y., Moreira, F., Sirami, C., Schindler, S., Müller, R., Bontzorlos, V., Clough, D., Bezák, P., Bonn, A., Hansjürgens, B., Lomba, A., Möckel, S., Passoni, G., Schleyer, C., Schmidt, J., and Lakner, S., 2019. A greener path for the EU Common Agricultural Policy. Science $365,449-451$.

Pérez-Jaramillo, J.E., Mendes, R., and Raaijmakers, J.M., 2016. Impact of plant domestication on rhizosphere microbiome assembly and functions. Plant Mol. Biol. 90, 635-644.

Peterson, B.D., McDaniel, E.A., Schmidt, A.G., Lepak, R.F., Janssen, S.E., Tran, P.Q., Marick, R.A., Ogorek, J.M., DeWild, J.F., Krabbenhoft, D.P., and McMahon, K.D., 2020. Mercury Methylation Genes Identified across Diverse Anaerobic Microbial Guilds in a Eutrophic Sulfate-Enriched Lake. Environ. Sci. Technol. 54, 15840-15851.

Philippot, L., Bru, D., Saby, N.P.A., Cuhel, J., Arrouays, D., Simek, M., and Hallin, S., 2009. Spatial patterns of bacterial taxa in nature reflect ecological traits of deep branches of the $16 \mathrm{~S}$ rRNA bacterial tree. Environ. Microbiol.11, 3096-3104.

Philippot, L., and Hallin, S., 2011. Towards food, feed and energy crops mitigating climate change. Trends Plant Sci. 16, 476-480.

Philippot, L., Raaijmakers, J.M., Lemanceau, P., and van der Putten, W.H., 2013. Going back to the roots: the microbial ecology of the rhizosphere. Nat. Rev. Microbiol. 11, 789-99.

Pieterse, C.M.J., Zamioudis, C., Berendsen, R.L., Weller, D.M., Wees, S.C.M.V., and Bakker, P.A. H.M., 2014. Induced Systemic Resistance by Beneficial Microbes. Annu. Rev. Phytopathol. 52, 347-375.

Poeplau, C., Helfrich, M., Dechow, R., Szoboszlay, M., Tebbe, C.C., Don, A., Greiner, B., Zopf, D., Thumm, U., Korevaar, H., and Geerts, R., 2019. Increased microbial anabolism 
contributes to soil carbon sequestration by mineral fertilization in temperate grasslands. Soil Biol. Biochem. 130, 167-176.

Põlme, S., Abarenkov, K., Henrik Nilsson, R., Lindahl, B.D., Clemmensen, K.E., Kauserud, H., Nguyen, N., Kjøller, R., Bates, S. T., Baldrian, P., Frøslev, T.G., Adojaan, K., Vizzini, A., Suija, A., Pfister, D., Baral, H.-O., Järv, H., Madrid, H., Nordén, J., Liu, J.-K., Pawlowska, J., Põldmaa, K., Pärtel, K., Runnel, K., Hansen, K., Larsson, K.-H., Hyde, K. D., SandovalDenis, M., Smith, M.E., Toome-Heller, M., Wijayawardene, N.N., Menolli, N., Reynolds, N.K., Drenkhan, R., Maharachchikumbura, S.S.N., Gibertoni, T.B., Læssøe, T., Davis, W., Tokarev, Y., Corrales, A., Soares, A.M., Agan, A., Machado, A.R., Argüelles-Moyao, A., Detheridge, A., de Meiras-Ottoni, A., Verbeken, A., Dutta, A.K., Cui, B.-K., Pradeep, C.K., Marín, C., Stanton, D., Gohar, D., Wanasinghe, D.N., Otsing, E., Aslani, F., Griffith, G.W., Lumbsch, T.H., Grossart, H.-P., Masigol, H., Timling, I., Hiiesalu, I., Oja, J., Kupagme, J.Y., Geml, J., Alvarez-Manjarrez, J., Ilves, K., Loit, K., Adamson, K., Nara, K., Küngas, K., RojasJimenez, K., Bitenieks, K., Irinyi, L., Nagy, L.G., Soonvald, L., Zhou, L.-W., Wagner, L., Aime, M.C., Öpik, M., Mujica, M.I., Metsoja, M., Ryberg, M., Vasar, M., Murata, M., Nelsen, M.P., Cleary, M., Samarakoon, M.C., Doilom, M., Bahram, M., Hagh-Doust, N., Dulya, O., Johnston, P., Kohout, P., Chen, Q., Tian, Q., Nandi, R., Amiri, R., Perera, R.H., dos Santos Chikowski, R., et al., 2020. FungalTraits: a user-friendly traits database of fungi and fungus-like stramenopiles. Fungal Divers. 105, 1-16.

Polz, M.F., Alm, E.J., and Hanage, W.P., 2013. Horizontal gene transfer and the evolution of bacterial and archaeal population structure. Trends Genet. 29, 170-175.

Power, A.G., 2010. Ecosystem services and agriculture: tradeoffs and synergies. Philos. Trans. R. Soc. Lond., B, Biol. Sci. 365, 2959-2971.

Prosser, J.I., 2015. Dispersing misconceptions and identifying opportunities for the use of 'omics' in soil microbial ecology. Nat. Rev. Microbiol. 13, 439-46.

Qian, H., Huang, S., Chen, J., Wang, L., Hungate, B. A., van Kessel, C., Zhang, J., Deng, A., Jiang, Y., van Groenigen, K.J., and Zhang, W., 2020. Lower-than-expected $\mathrm{CH}_{4}$ emissions from rice paddies with rising $\mathrm{CO}_{2}$ concentrations. Glob. Chang. Biol. 26, 2368-2376. 
Raguideau, S., Plancade, S., Pons, N., Leclerc, M., and Laroche, B., 2016. Inferring Aggregated Functional Traits from Metagenomic Data Using Constrained Non-negative Matrix Factorization: Application to Fiber Degradation in the Human Gut Microbiota. PLoS Comput. Biol. 12, e1005252.

Rasmann, S., Bennett, A., Biere, A., Karley, A., and Guerrieri, E., 2017. Root symbionts: Powerful drivers of plant above- and belowground indirect defenses. Insect Sci. 24, 947-960.

Ray, P., Lakshmanan, V., Labbé, J.L., and Craven, K.D., 2020. Microbe to Microbiome: A Paradigm Shift in the Application of Microorganisms for Sustainable Agriculture. Front. Microbiol. 11, 11:622926.

Read, D.J., Leake, J.R., and Perez-Moreno, J., 2004. Mycorrhizal fungi as drivers of ecosystem processes in heathland and boreal forest biomes. Can. J. Bot. 82, 1243-1263.

Remus-Emsermann, M.N.P., Tecon, R., Kowalchuk, G.A., and Leveau, J.H.J., 2012. Variation in local carrying capacity and the individual fate of bacterial colonizers in the phyllosphere. ISME J. 6, 756-765.

Rey, O., Eizaguirre, C., Angers, B., Baltazar-Soares, M., Sagonas, K., Prunier, J.G., and Blanchet, S., 2020. Linking epigenetics and biological conservation: Towards a conservation epigenetics perspective. Funct. Ecol. 34, 414-427.

Rillig, M.C., Aguilar-Trigueros, C.A., Bergmann, J., Verbruggen, E., Veresoglou, S.D., and Lehmann, A., 2015. Plant root and mycorrhizal fungal traits for understanding soil aggregation. New Phytol. 205, 1385-1388.

Rodríguez, H., and Fraga, R., 1999. Phosphate solubilizing bacteria and their role in plant growth promotion. Biotechnol. Adv. 17, 319-339.

Rosado, B.H.P., Almeida, L.C., Alves, L.F., Lambais, M.R., and Oliveira, R.S., 2018. The importance of phyllosphere on plant functional ecology: a phyllo trait manifesto. New Phytol. 219, 1145-1149.

Saleem, M., and Moe, L.A., 2014. Multitrophic microbial interactions for eco- and agrobiotechnological processes: theory and practice. Trends Biotechnol. 32, 529-537. 
Salles, J.F., Le Roux, X., and Poly, F., 2012. Relating phylogenetic and functional diversity among denitrifiers and quantifying their capacity to predict community functioning. Front. Microbiol. 3, 3:209.

Salles, J.F., Poly, F., Schmid, B., and Le Roux, X., 2009. Community niche predicts the functioning of denitrifying bacterial assemblages. Ecology 90, 3324-3332.

Saunois, M., Stavert, A.R., Poulter, B., Bousquet, P., Canadell, J.G., Jackson, R.B., Raymond, P.A., Dlugokencky, E.J., Houweling, S., Patra, P.K., Ciais, P., Arora, V.K., Bastviken, D., Bergamaschi, P., Blake, D.R., Brailsford, G., Bruhwiler, L., Carlson, K.M., Carrol, M., Castaldi, S., Chandra, N., Crevoisier, C., Crill, P.M., Covey, K., Curry, C. L., Etiope, G., Frankenberg, C., Gedney, N., Hegglin, M.I., Höglund-Isaksson, L., Hugelius, G., Ishizawa, M., Ito, A., Janssens-Maenhout, G., Jensen, K.M., Joos, F., Kleinen, T., Krummel, P.B., Langenfelds, R.L., Laruelle, G.G., Liu, L., Machida, T., Maksyutov, S., McDonald, K.C., McNorton, J., Miller, P.A., Melton, J.R., Morino, I., Müller, J., Murguia-Flores, F., Naik, V., Niwa, Y., Noce, S., O'Doherty, S., Parker, R.J., Peng, C., Peng, S., Peters, G.P., Prigent, C., Prinn, R., Ramonet, M., Regnier, P., Riley, W.J., Rosentreter, J.A., Segers, A., Simpson, I. J., Shi, H., Smith, S.J., Steele, L.P., Thornton, B.F., Tian, H., Tohjima, Y., Tubiello, F.N., Tsuruta, A., Viovy, N., Voulgarakis, A., Weber, T.S., van Weele, M., van der Werf, G.R., Weiss, R.F., Worthy, D., Wunch, D., Yin, Y., Yoshida, Y., Zhang, W., Zhang, Z., Zhao, Y., Zheng, B., Zhu, Q., Zhu, Q., and Zhuang, Q., 2020. The Global Methane Budget 20002017. Earth Syst. Sci. Data 12, 1561-1623.

Schlatter, D., Kinkel, L., Thomashow, L., Weller, D., and Paulitz, T., 2017. Disease Suppressive Soils: New Insights from the Soil Microbiome. Phytopathology 107, 1284-1297.

Schoener, T.W., 2011. The Newest Synthesis: Understanding the Interplay of Evolutionary and Ecological Dynamics. Science 331, 426-429.

Schweitzer, J.A., Bailey, J.K., Rehill, B.J., Martinsen, G.D., Hart, S.C., Lindroth, R.L., Keim, P., and Whitham, T.G., 2004. Genetically based trait in a dominant tree affects ecosystem processes. Ecol. Lett. 7, 127-134. 
Schweitzer, J.A., Juric, I., van de Voorde, T.F.J., Clay, K., van der Putten, W.H., and Bailey, J.K., 2014. Are there evolutionary consequences of plant-soil feedbacks along soil gradients? Funct. Ecol. 28, 55-64.

Sheard, C., Neate-Clegg, M.H.C., Alioravainen, N., Jones, S.E.I., Vincent, C., MacGregor, H.E.A., Bregman, T.P., Claramunt, S., and Tobias, J.A., 2020. Ecological drivers of global gradients in avian dispersal inferred from wing morphology. Nat. Commun. 11, 2463.

Shen, L.-d., Liu, J.-q., Yang, Y.-I., Bai, Y.-n., Yang, W.-t., Tian, M.-h., Liu, X., Jin, J.-h., Han, M.-j., Ren, B.-j., Pan, Y.-y., and Wu, H.-s., 2021. Activity, abundance and community composition of nitrite-dependent methanotrophs in response to fertilization in paddy soils. Appl. Soil Ecol. 166, 103987.

Singh, R., Shelke, G., Kumar, A., and Jha, P., 2015. Biochemistry and genetics of ACC deaminase: a weapon to "stress ethylene" produced in plants. Front. Microbiol. 6, 6:937.

Slangen, J.H.G., and Kerkhoff, P., 1984. Nitrification inhibitors in agriculture and horticulture: A literature review. Fertilizer research 5, 1-76.

Smith, F.A., Grace, E.J., and Smith, S.E., 2009. More than a carbon economy: nutrient trade and ecological sustainability in facultative arbuscular mycorrhizal symbioses. New Phytol. $182,347-358$.

Smith, S.E., and Smith, F.A., 2011. Roles of arbuscular mycorrhizas in plant nutrition and growth: new paradigms from cellular to ecosystem scales. Annu. Rev. Plant. Biol. 62, 227-50.

Solano, C., Echeverz, M., and Lasa, I., 2014. Biofilm dispersion and quorum sensing. Curr. Opin. Microbiol. 18, 96-104.

Soudzilovskaia, N.A., van Bodegom, P.M., Terrer, C., Zelfde, M.v.t., McCallum, I., Luke McCormack, M., Fisher, J.B., Brundrett, M.C., de Sá, N.C., and Tedersoo, L., 2019. Global mycorrhizal plant distribution linked to terrestrial carbon stocks. Nat. Commun. 10, 5077.

Soudzilovskaia, N.A., van der Heijden, M.G.A., Cornelissen, J.H.C., Makarov, M.I., Onipchenko, V.G., Maslov, M.N., Akhmetzhanova, A.A., and van Bodegom, P.M., 2015. Quantitative 
assessment of the differential impacts of arbuscular and ectomycorrhiza on soil carbon cycling. New Phytol. 208, 280-293.

Spor, A., Roucou, A., Mounier, A., Bru, D., Breuil, M.-C., Fort, F., Vile, D., Roumet, P., Philippot, L., and Violle, C., 2020. Domestication-driven changes in plant traits associated with changes in the assembly of the rhizosphere microbiota in tetraploid wheat. Sci. Rep. 10, 12234.

Staley, J.T., 2006. The bacterial species dilemma and the genomic-phylogenetic species concept. Philos. Trans. R. Soc. Lond., B, Biol. Sci. 361, 1899-909.

Steenbergh, A.K., Veraart, A.J., Ho, A., and Bodelier, P.L.E., 2017. Microbial Ecosystem Functions in Wetlands under Disturbance. In Tate, K.R (Eds.), Microbial Biomass A Paradigm Shift in Terrestrial Biogeochemistry, World Scientific Publishing, Singapore, pp. 227-274.

Su, J., Hu, C., Yan, X., Jin, Y., Chen, Z., Guan, Q., Wang, Y., Zhong, D., Jansson, C., Wang, F., Schnürer, A., and Sun, C., 2015. Expression of barley SUSIBA2 transcription factor yields high-starch low-methane rice. Nature 523, 602-606.

Subbarao, G.V., Rondon, M., Ito, O., Ishikawa, T., Rao, I.M., Nakahara, K., Lascano, C., and Berry, W.L., 2007. Biological nitrification inhibition, (BNI)-is it a widespread phenomenon? Plant Soil 294, 5-18.

Subbarao, G.V., Sahrawat, K.L., Nakahara, K., Rao, I.M., Ishitani, M., Hash, C. T., Kishii, M., Bonnett, D.G., Berry, W.L., and Lata, J.C., 2013. A paradigm shift towards low-nitrifying production systems: the role of biological nitrification inhibition, (BNI). Ann. Bot. 112, 297-316.

Sun, L., Lu, Y., Yu, F., Kronzucker, H.J., and Shi, W., 2016. Biological nitrification inhibition by rice root exudates and its relationship with nitrogen-use efficiency. New Phytol. 212, 646656.

Sutherland, W.J., Broad, S., Butchart, S.H.M., Clarke, S.J., Collins, A.M., Dicks, L.V., Doran, H., Esmail, N., Fleishman, E., Frost, N., Gaston, K.J., Gibbons, D.W., Hughes, A.C., Jiang, Z., Kelman, R., LeAnstey, B., le Roux, X., Lickorish, F.A., Monk, K.A., Mortimer, D., PearceHiggins, J.W., Peck, L.S., Pettorelli, N., Pretty, J., Seymour, C.L., Spalding, M.D., 
Wentworth, J., and Ockendon, N., 2019. A Horizon Scan of Emerging Issues for Global Conservation in 2019. Trends Ecol. Evol. 34, 83-94.

Syswerda, S., Corbin, A.T., Mokma, D.L., Kravchenko, A., and Robertson, G.P., 2011. Agricultural Management and Soil Carbon Storage in Surface vs. Deep Layers. Soil Sci. Soc. Am. 75, 92-101.

T. Weedon, J., A. Kowalchuk, G., Aerts, R., van Hal, J., van Logtestijn, R., Taş, N., F.M. Röling, W., and M. van Bodegom, P., 2012. Summer warming accelerates sub-arctic peatland nitrogen cycling without changing enzyme pools or microbial community structure. Glob. Chang. Biol. 18, 138-150.

Tedersoo, L., and Brundrett, M.C., 2017. Evolution of Ectomycorrhizal Symbiosis in Plants, in: Tedersoo, L. (Eds.), Biogeography of Mycorrhizal Symbiosis. Springer International Publishing, Cham, pp. 407-467.

terHorst, C.P., and Zee, P.C., 2016. Eco-evolutionary dynamics in plant-soil feedbacks. Funct. Ecol. 30, 1062-1072.

Treseder, K.K., and Lennon, J.T., 2015. Fungal traits that drive ecosystem dynamics on land. Microbiology and molecular biology reviews : Microbiol. Mol. Biol. Rev. 79, 243-262. Vaksmaa, A., Guerrero-Cruz, S., van Alen, T.A., Cremers, G., Ettwig, K.F., Lüke, C., and Jetten, M.S.M., 2017. Enrichment of anaerobic nitrate-dependent methanotrophic 'Candidatus Methanoperedens nitroreducens' archaea from an Italian paddy field soil. Appl. Microbiol. Biotechnol. 101, 7075-7084.

van Bodegom, P.M., 2007. Microbial maintenance: a critical review on its quantification. Microb. Ecol. 53, 513-523.

Van Bodegom, P. M., Douma, J.C., Witte, J.P.M., Ordonez, J.C., Bartholomeus, R.P., and Aerts, R., 2012. Going beyond limitations of plant functional types when predicting global ecosystem-atmosphere fluxes: exploring the merits of traits-based approaches. Glob. Ecol. Biogeogr. 21, 625-636.

Van Deynze, A., Zamora, P., Delaux, P.-M., Heitmann, C., Jayaraman, D., Rajasekar, S., Graham, D., Maeda, J., Gibson, D., Schwartz, K.D., Berry, A.M., Bhatnagar, S., Jospin, G., Darling, A., Jeannotte, R., Lopez, J., Weimer, B.C., Eisen, J.A., Shapiro, H.-Y., Ané, J.-M., and 
Bennett, A.B., 2018. Nitrogen fixation in a landrace of maize is supported by a mucilageassociated diazotrophic microbiota. PLOS Biol. 16, e2006352.

Vandenkoornhuyse, P., Quaiser, A., Duhamel, M., Le Van, A., and Dufresne, A., 2015. The importance of the microbiome of the plant holobiont. New Phytol. 206, 1196-1206.

Velusamy, P., Immanuel, J.E., Gnanamanickam, S.S., and Thomashow, L., 2006. Biological control of rice bacterial blight by plant-associated bacteria producing $2,4-$ diacetylphloroglucinol. Can. J. Microbiol. 52, 56-65.

Verbruggen, E., Röling, W.F., Gamper, H.A., Kowalchuk, G.A., Verhoef, H.A., and van der Heijden, M. G., 2010. Positive effects of organic farming on below-ground mutualists: large-scale comparison of mycorrhizal fungal communities in agricultural soils. New Phytol. 186, 968-79.

Verhoeven, K.J.F., vonHoldt, B.M., and Sork, V.L., 2016. Epigenetics in ecology and evolution: what we know and what we need to know. Mol. Ecol. 25, 1631-1638.

Violle, C., Navas, M.L., Vile, D., Kazakou, E., Fortunel, C., Hummel, I., and Garnier, E., 2007. Let the concept of trait be functional! Oikos 116, 882-892.

Vorholt, J. A., 2012. Microbial life in the phyllosphere. Nat Rev Microbiol 10, 828-40.

Wei, Z., and Jousset, A., 2017. Plant Breeding Goes Microbial. Trends Plant. Sci. 22, 555-558.

Wen, X., Yang, S., Horn, F., Winkel, M., Wagner, D., and Liebner, S., 2017. Global Biogeographic Analysis of Methanogenic Archaea Identifies Community-Shaping Environmental Factors of Natural Environments. Front Microbiol 8, 8:1339.

Willbanks, A., Leary, M., Greenshields, M., Tyminski, C., Heerboth, S., Lapinska, K., Haskins, K., and Sarkar, S., 2016. The Evolution of Epigenetics: From Prokaryotes to Humans and Its Biological Consequences. Genet. Epigenetics 8, GEG.S31863.

Wilson, D., 2016. Microbial Diversity and Cellulase Production, in: Vijai Kumar Gupta, V.K. (Eds.), New and Future Developments in Microbial Biotechnology and Bioengineering Microbial Cellulase System Properties and Applications. Elsevier, Amsterdam, pp. 43-48.

Wood, S.A., Karp, D.S., DeClerck, F., Kremen, C., Naeem, S., and Palm, C.A., 2015. Functional traits in agriculture: agrobiodiversity and ecosystem services. Trends Ecol. Evol. 30, 531539. 
Wu, Q., Hu, H., Meng, B., Wang, B., Poulain, A. J., Zhang, H., Liu, J., Bravo, A.G., Bishop, K., Bertilsson, S., and Feng, X., 2020. Methanogenesis Is an Important Process in Controlling MeHg Concentration in Rice Paddy Soils Affected by Mining Activities. Environ. Sci. Technol. 54, 13517-13526.

Xu, J., Buck, M., Eklöf, K., Ahmed, O. O., Schaefer, J.K., Bishop, K., Skyllberg, U., Björn, E., Bertilsson, S., and Bravo, A.G., 2019. Mercury methylating microbial communities of boreal forest soils. Sci. Rep. 9, 518.

Yan, Y., Yang, J., Dou, Y., Chen, M., Ping, S., Peng, J., Lu, W., Zhang, W., Yao, Z., Li, H., Liu, W., He, S., Geng, L., Zhang, X., Yang, F., Yu, H., Zhan, Y., Li, D., Lin, Z., Wang, Y., Elmerich, C., Lin, M., and Jin, Q., 2008. Nitrogen fixation island and rhizosphere competence traits in the genome of root-associated Pseudomonas stutzeri A1501. Proc. Natl. Acad. Sci. USA 105, 7564-7569.

Zakharova, L., Meyer, K.M., and Seifan, M., 2019. Trait-based modelling in ecology: A review of two decades of research. Ecol. Modell. 407, 108703.

Zanne, A.E., Abarenkov, K., Afkhami, M.E., Aguilar-Trigueros, C.A., Bates, S., Bhatnagar, J.M., Busby, P.E., Christian, N., Cornwell, W.K., Crowther, T.W., Flores-Moreno, H., Floudas, D., Gazis, R., Hibbett, D., Kennedy, P., Lindner, D.L., Maynard, D.S., Milo, A.M., Nilsson, R.H., Powell, J., Schildhauer, M., Schilling, J., and Treseder, K.K., 2020. Fungal functional ecology: bringing a trait-based approach to plant-associated fungi. Biol. Rev. Camb. Philos. Soc. 95, 409-433.

Zhao, L., Meng, B., and Feng, X., 2020. Mercury methylation in rice paddy and accumulation in rice plant: A review. Ecotoxicol. Environ. Saf. 195, 110462.

Zhou, Z., Wang, C., and Luo, Y., 2020. Meta-analysis of the impacts of global change factors on soil microbial diversity and functionality. Nat. Commun. 11, 3072.

Zhu, Q. H., Shan, W.X., Ayliffe, M.A., and Wang, M.B., 2016. Epigenetic Mechanisms: An Emerging Player in Plant-Microbe Interactions. Mol. Plant. Microbe Interact. 29, 187-96.

Zhu, Y.G., Smith, S.E., Barritt, A.R., and Smith, F.A., 2001. Phosphorus (P) efficiencies and mycorrhizal responsiveness of old and modern wheat cultivars. Plant Soil 237, 249-255. 
Table1: Glossary for trait-based approaches in microbial systems.

\begin{tabular}{|c|c|}
\hline & Comparative studies \\
\hline Functional trait & $\begin{array}{l}\text { Defined as measurable property of an organism that } \\
\text { impacts its fitness, i.e. growth, reproduction, survival) } \\
\text { or function and can correspond to a morphological, } \\
\text { physiological or genomic attribute, Violle et al., 2007). } \\
\text { In agroecosystems, relevant plant and microbial } \\
\text { functional traits can be considered as measurable } \\
\text { properties that impact plant health, plant growth, plant } \\
\text { resistance/resilience, soil quality, and adjacent } \\
\text { ecosystems. }\end{array}$ \\
\hline Taxa centered traits & $\begin{array}{l}\text { Traits of pure cultures, i.e. individual genome or } \\
\text { organism-based, taxa traits), Escalas et al., 2019) }\end{array}$ \\
\hline Community aggregated traits & $\begin{array}{l}\text { Mean value calculated for each trait as the mean trait } \\
\text { value in a community which can be weighted by the } \\
\text { relative abundance of individual taxa in a community, } \\
\text { Díaz et al., 2007; Violle et al., 2007). For microbes, } \\
\text { community aggregated traits can also be weighted by } \\
\text { using the abundance of relevant marker genes, } \\
\text { Raguideau et al., 2016). }\end{array}$ \\
\hline Response and effect trait & $\begin{array}{l}\text { A trait that drives an organism's response to abiotic or } \\
\text { biotic changes in the environment or an organism's } \\
\text { effect on ecosystem processes or characteristics, } \\
\text { Lavorel and Garnier, 2002) }\end{array}$ \\
\hline Eco-evolutionary feedback & $\begin{array}{l}\text { Eco-evolutionary feedback describes a process in which } \\
\text { ecology and evolution reciprocally interact with each } \\
\text { other, Govaert et al., 2018) }\end{array}$ \\
\hline Plant holobiont & $\begin{array}{l}\text { A holobiont is an ecological unit that consists of a host } \\
\text { organism and all organisms living in its surrounding, } \\
\text { Margulis, 1990). In the context of trait-based } \\
\text { approaches, it is the multipartite entities formed by the } \\
\text { host plant and its microbiome, Vandenkoornhuyse et } \\
\text { al., 2015). }\end{array}$ \\
\hline
\end{tabular}


Table 2: Examples of microbial functional traits, genotypic or phenotypical) important to processes in agroecosystems. 


\begin{tabular}{|c|c|c|c|c|c|}
\hline Component & Microbial mechanism & Simple and integrative traits & $\begin{array}{l}\text { Trait } \\
\text { category }\end{array}$ & Plant benefit & Reference \\
\hline \multirow[t]{3}{*}{$\begin{array}{l}\text { Plant nutrient } \\
\text { acquisition }\end{array}$} & $\mathrm{N}_{2}$ fixation & $\begin{array}{l}\text { Nitrogenase, Fe protein, NifH } \\
\text { gene) }\end{array}$ & Genome & $\begin{array}{l}\text { Nitrogen, } \mathrm{N} \text { ) is an important } \\
\text { component of Rubisco and } \\
\text { determines the maximum } \\
\text { photosynthetic rate. }\end{array}$ & $\begin{array}{l}\text { (Escalas et al., 2019; } \\
\text { Ormeño-Orrillo et } \\
\text { al., 2013) }\end{array}$ \\
\hline & $\begin{array}{l}\text { Phosphorous, P) } \\
\text { uptake }\end{array}$ & $\begin{array}{l}\text { Root-to-hyphae ratio; root- } \\
\text { to-hyphae distance }\end{array}$ & Phenotype & $\begin{array}{l}\text { Increase efficiency of } \\
\text { nutrient uptake by plants } \\
\text { through mycorrhizal fungi }\end{array}$ & (Smith et al., 2009) \\
\hline & P uptake & $\begin{array}{l}\text { Phosphatases, PhoD and } \\
\text { PhoX) }\end{array}$ & Genome & $\begin{array}{l}\text { Hydrolyze organic } P \text { to } \\
\text { orthophosphate, which } \\
\text { makes phosphorous } \\
\text { available to plants }\end{array}$ & $\begin{array}{l}\text { (Neal et al., 2017; } \\
\text { Rodríguez and Fraga, } \\
\text { 1999) }\end{array}$ \\
\hline Soil fertility & $\begin{array}{l}\text { Soil organic carbon } \\
\text { sequestration }\end{array}$ & $\begin{array}{l}\text { Microbial carbon use } \\
\text { efficiency, CUE) }\end{array}$ & Indicator & $\begin{array}{l}\text { Higher nitrogen availability } \\
\text { under fertilization improves } \\
\text { CUE thereby stabilizing } \\
\text { carbon storage and losses to } \\
\text { the soil }\end{array}$ & $\begin{array}{l}\text { (Kallenbach et al., } \\
\text { 2019; Poeplau et al., } \\
\text { 2019) }\end{array}$ \\
\hline Soil fertility & $\begin{array}{l}\text { Decomposition, } \\
\text { recalcitrant carbon } \\
\text { deposition, } \mathrm{N} \text { and } \mathrm{P} \\
\text { transformations }\end{array}$ & Variety of functional genes & Genome & Plant nutrition & $\begin{array}{l}\text { (Treseder and } \\
\text { Lennon, 2015) }\end{array}$ \\
\hline $\begin{array}{l}\text { Plant growth, } \\
\text { pathogenicity }\end{array}$ & $\begin{array}{l}\text { Phytohormone } \\
\text { production, Indole-3- } \\
\text { acetic acid, IAA) }\end{array}$ & $\begin{array}{l}\text { Indolepyruvate } \\
\text { decarboxylase, }(p d C), \\
\text { Tryptophan monooxygenase, } \\
\text { (aaM), Phenylacetaldoxime } \\
\text { dehydratase, Oxd) and } \\
\text { Nitrile hydratase, Nhd1) } \\
\end{array}$ & Genome & $\begin{array}{l}\text { Modulating plant growth and } \\
\text { development; but can also } \\
\text { facilitate phytopathogenicity }\end{array}$ & (Duca et al., 2014) \\
\hline Plant growth & Volatile production & Dimethyl trisulfides & Indicator & $\begin{array}{l}\text { increase in shoot weight at } 1 \\
\text { micromolar and negative } \\
\text { effects on plant biomass at } \\
\text { concentrations }>1 \text { millimolar }\end{array}$ & $\begin{array}{l}\text { (Cordovez et al., } \\
\text { 2018) }\end{array}$ \\
\hline
\end{tabular}




\begin{tabular}{|c|c|c|c|c|c|}
\hline Plant defense & $\begin{array}{l}\text { Stress protection, e.g. } \\
\text { salt, drought, plant } \\
\text { pathogen) }\end{array}$ & $\begin{array}{l}\text { 1-aminocyclopropane-1- } \\
\text { carboxylate deaminase, } A c d S \text { ) }\end{array}$ & Genome & $\begin{array}{l}\text { Synthesis of enzymes such as } \\
\text { ACC deaminase that } \\
\text { modulate the level of plant } \\
\text { hormones }\end{array}$ & (Singh et al., 2015) \\
\hline Plant defense & $\begin{array}{l}\mathrm{N} \text {-acyl homoserine } \\
\text { lactone, } \mathrm{AHL}) \\
\text { degradation }\end{array}$ & $\begin{array}{l}\text { AHL lactonase, e.g. aiiA), } \mathrm{AHL} \\
\text { acylase, e.g. aiiD) }\end{array}$ & Genome & $\begin{array}{l}\text { Can interfere with pathogen- } \\
\text { pathogen communication } \\
\text { and prevent virulence gene } \\
\text { expression }\end{array}$ & (Kalia et al., 2011) \\
\hline Plant defense & Soil suppression & $\begin{array}{l}\text { Chitinase genes, } \\
\text { nonribosomal peptide } \\
\text { synthetases, NRPSs) and } \\
\text { polyketide synthases, PKSs) }\end{array}$ & Genome & $\begin{array}{l}\text { Suppressed fungal root } \\
\text { disease }\end{array}$ & (Carrión et al., 2019) \\
\hline Plant toxicity & $\begin{array}{l}\text { Mercury, } \mathrm{Hg} \text { ) } \\
\text { methylation }\end{array}$ & $\begin{array}{l}\text { Corrin and ferro-reduced } \\
\text { protein, } h g c A B \text { genes) }\end{array}$ & Genomic & $\begin{array}{l}\text { Transformation of inorganic } \\
\text { Hg to methylmercury under } \\
\text { anaerobic conditions, with } \\
\text { accumulation in crops) }\end{array}$ & $\begin{array}{l}\text { (Wu et al., 2020; } \\
\text { Zhao et al., 2020) }\end{array}$ \\
\hline
\end{tabular}




\section{$0 \quad$ Figure legends}

1 Figure 1: Temporal variation in the total number of publications referring themselves to the

2 trait-based concept or framework for plants, black squares) and microbes, black dots), and in

3 particular the number of these publications in the context of agriculture, same symbols but in

4 grey). Search terms and methodology are provided in Supplementary Material.

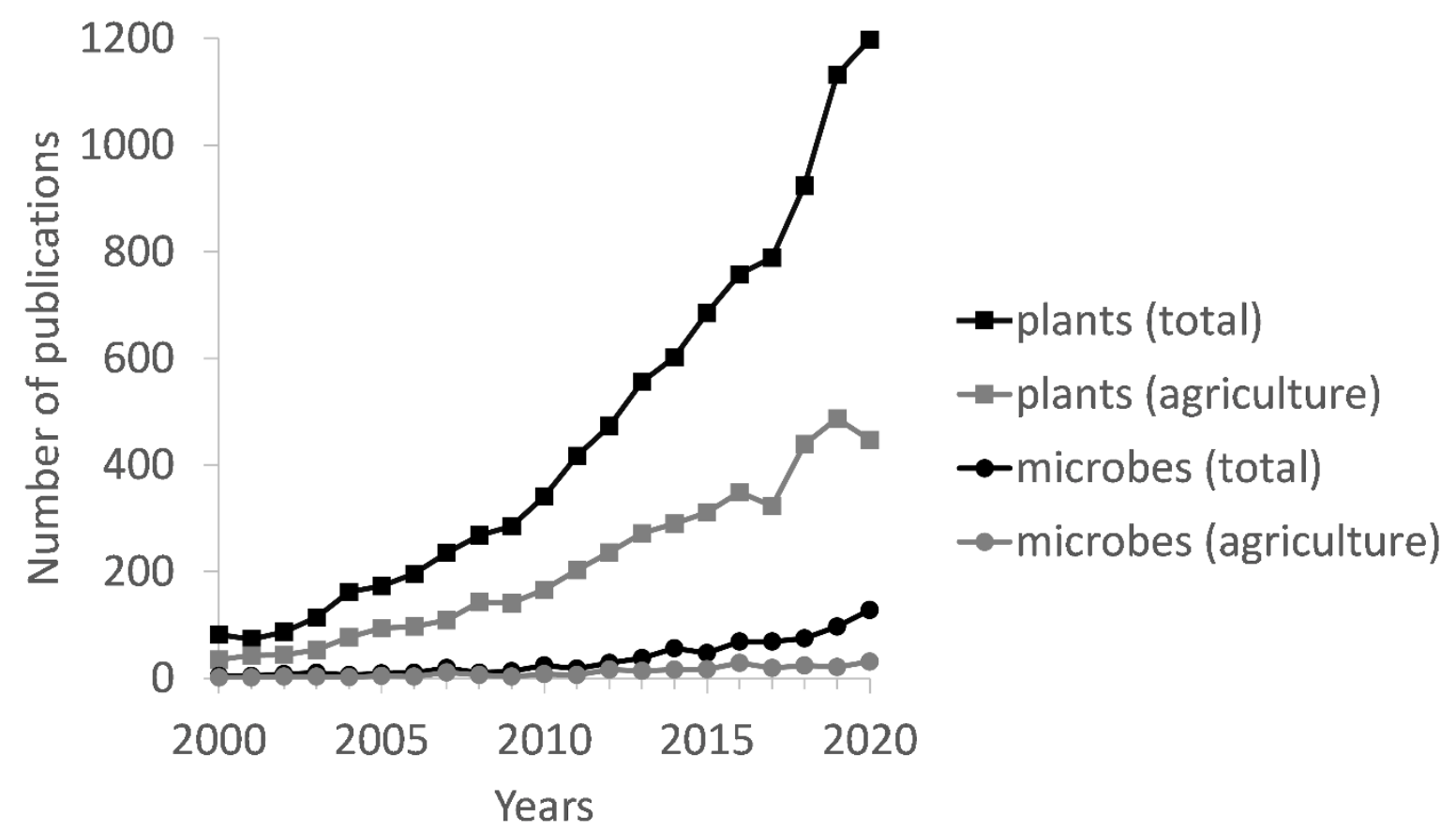


From challenges to develop microbial trait-based approaches for agriculture...

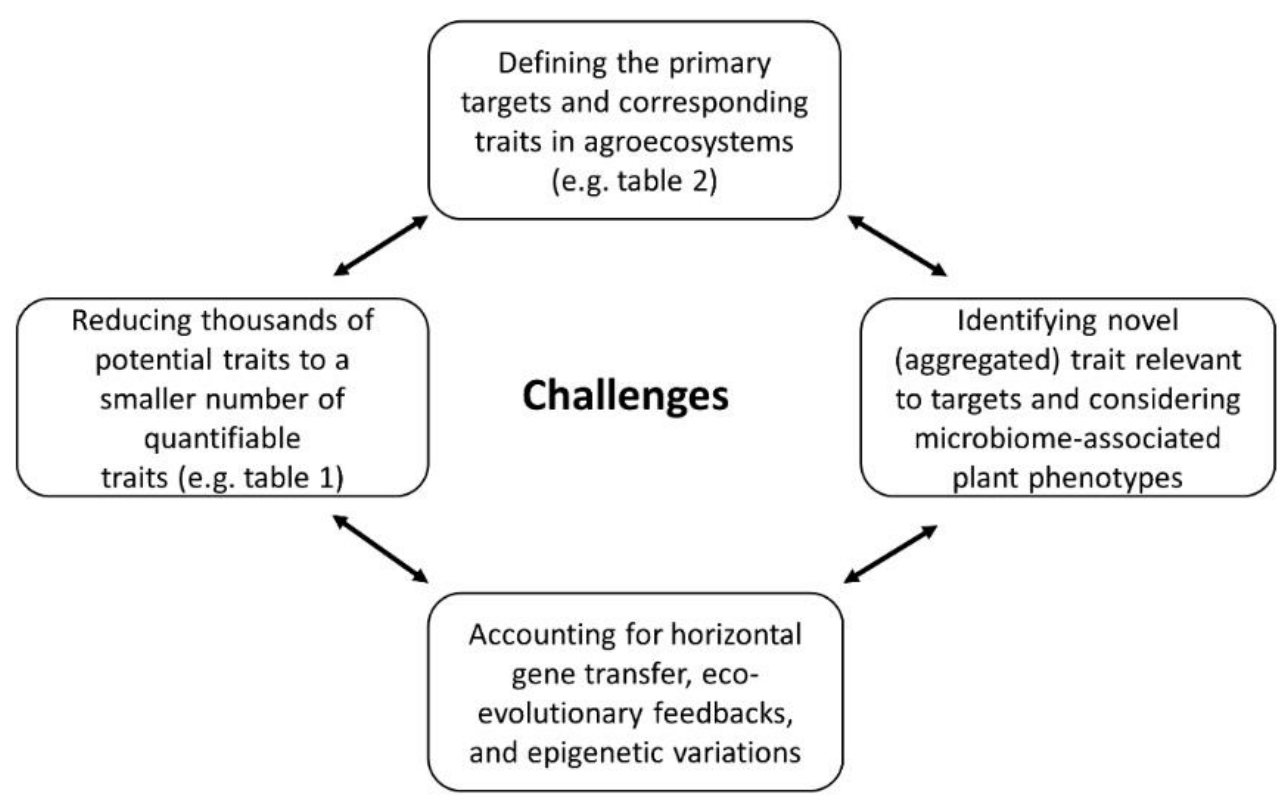

...to application in agriculture

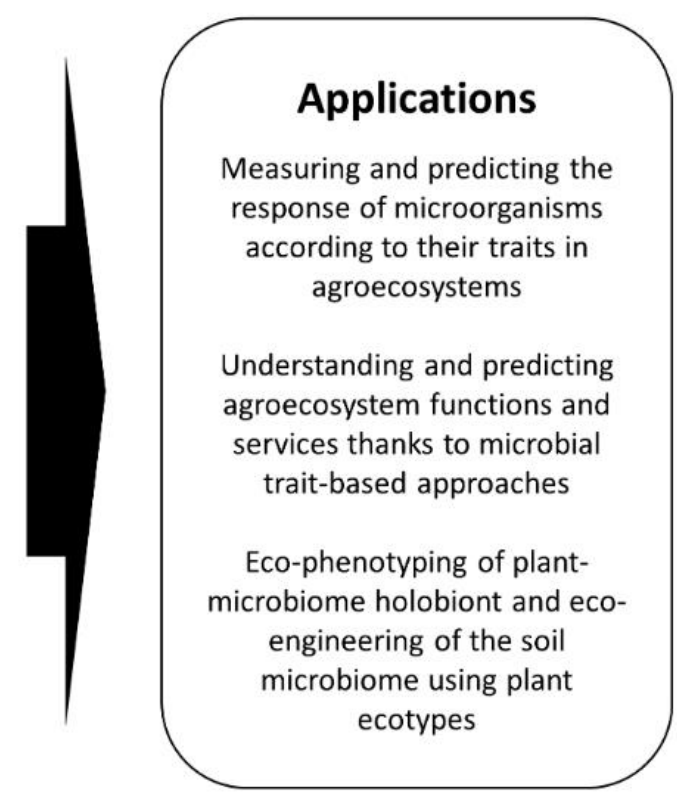

